Article

\title{
Ammonium-Salt Formation and Catalyst Deactivation in the SCR System for a Marine Diesel Engine
}

\author{
Yuanqing Zhu ${ }^{\mathbb{D}}$, Qichen Hou, Majed Shreka, Lu Yuan, Song Zhou*, Yongming Feng and \\ Chong Xia \\ College of Power and Energy Engineering, Harbin Engineering University, Harbin 150001, China; \\ zhuyuanqing@hrbeu.edu.cn (Y.Z.); houqichen@hrbeu.edu.cn (Q.H.); majed.shreka@outlook.com (M.S.); \\ yuanlu@hrbeu.edu.cn (L.Y.); fengyongming@hrbeu.edu.cn (Y.F.); xiachong@hrbeu.edu.cn (C.X.) \\ * Correspondence: exhaust@hrbeu.edu.cn; Tel.: +86-451-82568384
}

Received: 2 December 2018; Accepted: 21 December 2018; Published: 28 December 2018

\begin{abstract}
Due to the low temperature and complex composition of the exhaust gas of the marine diesel engine, the working requirements of the selective catalytic reduction (SCR) catalyst cannot be met directly. Moreover, ammonium sulfate, ammonium nitrate, and other ammonium deposits are formed at low temperatures, which block the surface or the pore channels of the SCR catalyst, thereby resulting in its reduction or even its loss of activity. Considering the difficulty of the marine diesel engine bench test and the limitation of the catalyst sample test, a one-dimensional simulation model of the SCR system was built in this paper. In addition, the deactivation reaction process of the ammonium salt in the SCR system and its influencing factors were studied. Based on the gas phase and the surface reaction kinetics, the models of the urea decomposition, the surface denitrification, the nitrate deactivation, and the sulfate deactivation were both constructed and verified in terms of accuracy. Moreover, the formation/decomposition reaction pathway and the catalytic deactivation of ammonium nitrate and ammonium bisulfate, as well as the composition concentration and the exhaust gas temperature range were correspondingly clarified. The results showed that within a certain range, the increase of the $\mathrm{NO}_{2} / \mathrm{NO}_{\mathrm{x}}$ ratio was conducive to the fast $\mathrm{SCR}$ reaction and the $\mathrm{NH}_{4} \mathrm{NO}_{3}$ formation's reaction. Increasing the exhaust gas temperature also raised the $\mathrm{NO}_{2} / \mathrm{NO}_{\mathrm{x}}$ ratio, which was beneficial to both the fast $\mathrm{SCR}$ reaction and the $\mathrm{NH}_{4} \mathrm{NO}_{3}$ decomposition reaction, respectively. Furthermore, the influence of the $\mathrm{SO}_{2}$ concentration on the denitrification efficiency decreased with the increase of the exhaust gas temperature because of increasing SCR reaction rate and reversibility of ammonia sulfate formation, and when the temperature of the exhaust gas was higher than $350^{\circ} \mathrm{C}$, the activity of the catalyst was almost unaffected by ammonia sulfate.
\end{abstract}

Keywords: SCR system; marine low-speed diesel engine; ammonium nitrate formation; ammonium sulfate formation; deactivation reaction

\section{Introduction}

Since marine diesel engines use low-quality fuel, their exhaust gases contain a lot of nitrogen oxides (NOx), sulfur oxide (SOx), particulate matter (PM), and other pollutants [1,2], which cause serious problems to both the marine environment and the atmosphere, respectively. In order to reduce the pollution of ship exhaust emissions in the atmosphere, the International Maritime Organization (IMO), the European Union, and the United States of America have formulated strict regulations [3], which concern the relevant ports and routes of Europe and North America. China also plans to extend the existing Emission Control Area to all sea areas within 12 nautical miles of the coasts and ports [4] that will surely have an impact on the related sea routes. 
Currently, selective catalytic reduction (SCR) is the only technology recognized by the International Maritime Organization (IMO) that is used to reduce $\mathrm{NO}_{\mathrm{x}}$ emissions in all kinds of marine engines [5], which theoretically meets the IMO Tier III regulation and the other stricter emission standards.

The low temperature and complex composition of the exhaust gas of the marine diesel engine do not allow the meeting with the working requirements of the SCR system directly, which later strongly limits the denitration efficiency. The SCR system of the two-stroke low-speed diesel engine must use different host modulation technologies to heat up the exhaust gas and obtain a higher denitration efficiency. Nevertheless, due to the different emission regulations in different sea areas, the SCR system adopts a discontinuous operation mode. Under this mode, the cold wall surface and the upwind surface of the catalyst will easily be blocked, resulting in more consumption and in waste of the reducing agent.

A SCR reaction is a kind of gas-solid multiphase reaction, which occurs on the surface of the catalyst and mainly includes the standard SCR reaction, the fast SCR reaction, the slow SCR reaction, and the side reaction, respectively [6,7]. Due to the oxygen-enriched combustion of the diesel engines, the exhaust gas contains a large amount of NO. Therefore, the denitration efficiency of the SCR system is concluded to be mainly limited by the standard SCR reaction and the fast SCR reaction. At low-temperature conditions, $\mathrm{SO}_{x}$ and $\mathrm{NO}_{x}$ (which are acidic gases) easily react with $\mathrm{NH}_{3}$ to form sulfate nitrates. Under the same conditions, ammonium sulfate and ammonium nitrate can be generated when there is a large number of $\mathrm{SO}_{\mathrm{x}}$ and $\mathrm{H}_{2} \mathrm{O}$ in the exhaust gas that blocks the surface and the pore channel of the catalyst [8,9], thereby reducing its activity. These ammonium salts mainly include ammonium sulfate $\left(\left(\mathrm{NH}_{4}\right) 2 \mathrm{SO}_{4}\right)$, ammonium bisulfate $\left(\mathrm{NH}_{4} \mathrm{HSO}_{4}\right)$, ammonium sulfite $\left(\left(\mathrm{NH}_{4}\right) 2 \mathrm{SO}_{3}\right)$, ammonium bisulfite $\left(\mathrm{NH}_{4} \mathrm{HSO}_{3}\right)$, ammonium nitrate $\left(\mathrm{NH}_{4} \mathrm{NO}_{3}\right)$, etc., which are relatively unstable and easy to decompose at high temperatures. In other words, after the formation of those ammonium salts, the activity of the catalyst can be recovered by high-temperature treatment. Therefore, the ammonium salt reactions can be termed as the catalytic deactivation of ammonium salt. Mathias Magnusson [8] believes that the formation of ammonium sulfate in the marine vanadium oxide catalysts can be relieved or avoided when the temperature is high enough (over $300{ }^{\circ} \mathrm{C}$ ) and also while the space velocity (below $12,200 \mathrm{~h}^{-1}$ ) and the SOx concentration are low enough. Currently, there are few studies on the catalysts under the conditions of marine diesel engine exhaust gas [6,7,9-11]. Nevertheless, studies on the sulfur poisoning of the catalyst samples have been carried out under laboratory conditions [12-18]. Sulfur poisoning of the SCR system can be divided into two types: first, SOx is in the gas phase and can react with the heavy metals on the catalyst surface generating stable substances [13,14]. Secondly, both $\mathrm{SO}_{x}$ and $\mathrm{NH}_{3}$ are presented in the exhaust gas, which can cause the formation of ammonium salt [15-18]. The difference between them is that the former is irreversible (catalyst inactivation) and the latter is reversible (activity inactivation).

The dew point of ammonium bisulfate salt is between $280 \sim 320^{\circ} \mathrm{C}$ and the formation of this salt inside the SCR system limit the catalyst minimum operating temperature [15]. When the temperature is below the dew point, ammonia gas and sulfuric acid steam condense into ammonium bisulfate, which block the surface structure of the catalyst $[16,17]$. Though the process is reversible, ammonium bisulfate will evaporate when the temperature is raised above the dew point along with the catalyst activity being restored. Nonetheless, the catalyst operating temperature will be lower than the dew point for a long time leading its activity to change permanently—causing the catalyst to deactivate [17]. At the same time, $\mathrm{V}_{2} \mathrm{O}_{5}$ in the catalyst will promote the oxidation of the $\mathrm{SO}_{2}$ in the exhaust gas to $\mathrm{SO}_{3}$, which will intensify the formation of ammonium sulfate salt [18].

Different from ammonium sulfate, the role of ammonium nitrate is mainly reflected in two points: first, the reaction of $\mathrm{NH}_{4} \mathrm{NO}_{2}$, the intermediate product of the fast SCR reaction pathway, is inhibited [19-22]; second, the surface structure of the catalyst is blocked. Despite this, nitrate is easier to decompose as compared to sulfate-it can decompose at only $170{ }^{\circ} \mathrm{C}$ [22]. 
Since the marine diesel engines burn sulfur-containing fuels (sulfur content more than $3.5 \%$ $\mathrm{m} / \mathrm{m}$ ), the temperature of the exhaust gas remains low (below $200{ }^{\circ} \mathrm{C}$ ) and the SOx concentration of the exhaust gas goes higher (more than $700 \mathrm{ppm}$ ) [1,2]. In addition, the SCR system working temperature will certainly be in the range of the ammonium hydrochloric acid's dew point. Therefore, the influence of sulfate and nitrate on the denitration efficiency must be considered when the engine matches the SCR system. However, the marine diesel engine has high power (MW grade) and large fuel consumption, which makes it difficult to carry out a larger number of reliability endurance tests. Hence, it is necessary to build a simulation model of the marine diesel engine SCR system to study the influence of the ammonium salt passivation reaction on the SCR system.

\section{Results and Discussions}

\subsection{The Simulation Analysis of the Catalyst Activity}

According to the working characteristics of the low-speed diesel engine SCR system, the exhaust gas temperature range was from 150 to $500{ }^{\circ} \mathrm{C}$ and the speed velocity was $10,000 \mathrm{~h}^{-1}$. And the main parameters of the catalyst used in the SCR system are shown in the Table 1 . In addition, the concentration of $\mathrm{NO}, \mathrm{NO}_{2}, \mathrm{NH}_{3}, \mathrm{O}_{2}$, and $\mathrm{H}_{2} \mathrm{O}$ were 900 ppm, $100 \mathrm{ppm}, 1000 \mathrm{ppm}, 15 \%$, and 3\%, respectively. Based on the SCR system model, this section simulated the change of the denitration efficiency of vanadium-based catalysts at different temperatures. The simulation results are shown in Figure 1.

Table 1. Main parameters of the catalyst used in the selective catalytic reduction (SCR) system.

\begin{tabular}{cc}
\hline Parameters & Data \\
\hline Catalyst type & $\mathrm{V}_{2} \mathrm{O}_{5}-\mathrm{WO}_{3} / \mathrm{TiO}_{2}$ \\
Cross-sectional area of catalyst $/ \mathrm{m}^{2}$ & 2 \\
Catalyst height $/ \mathrm{m}$ & 1.45 \\
Pore density of catalyst $/\left(1 / \mathrm{in}^{2}\right)$ & 19 \\
Dispersion length of catalyst $/ \mathrm{mm}$ & 50 \\
\hline
\end{tabular}

As shown in Figure 1, at steady state conditions, the denitrification efficiency tends to increase and then decrease slightly with the increase of the exhaust gas temperature, while the ammonia slip rate declines. At $350{ }^{\circ} \mathrm{C}$, the denitration efficiency reaches the maximum value $95 \%$, while the ammonia slip rate is $44 \mathrm{ppm}$. Conversely, the denitration efficiency is only $8.4 \%$ and the ammonia slip rate is $875 \mathrm{ppm}$ at an exhaust gas temperature of $150{ }^{\circ} \mathrm{C}$. Moreover, the overall ammonia slip rate simulation value is high because the constructed SCR system model ignores part of the $\mathrm{NH}_{3}$ oxidation pathway and the minimum ammonia slip rate is $26 \mathrm{ppm}$ at $500{ }^{\circ} \mathrm{C}$. According to the IMO Tier I and Tier III emission standards, the $\mathrm{NO}_{x}$-weighted emission level of the marine low-speed diesel engines is reduced by $80 \%$. Therefore, the activation temperature of the vanadium-based catalyst may be selected from 300 to $500{ }^{\circ} \mathrm{C}$.

$\mathrm{NO}_{\mathbf{x}}, \mathrm{SO}_{2}$ and $\mathrm{NH}_{3}$ in the exhaust gas will form deposits such as ammonium nitrate, ammonium sulfate, and ammonium bisulfate under the action of the catalyst, which will block the catalyst pores, cover the active centers of its surface, and lower its activity. In addition, the thermal decomposition temperatures of ammonium sulfate and ammonium bisulfate are in the range of 213 to $308{ }^{\circ} \mathrm{C}$ and 308 to $419{ }^{\circ} \mathrm{C}$, respectively, which also cover the low-speed diesel engine exhaust gas temperatures range. However, it is still difficult to decompose the sulfate on the catalyst surface at a lower temperature. Therefore, increasing the operating temperature of the SCR system is the main method to avoid sulfate formation. 


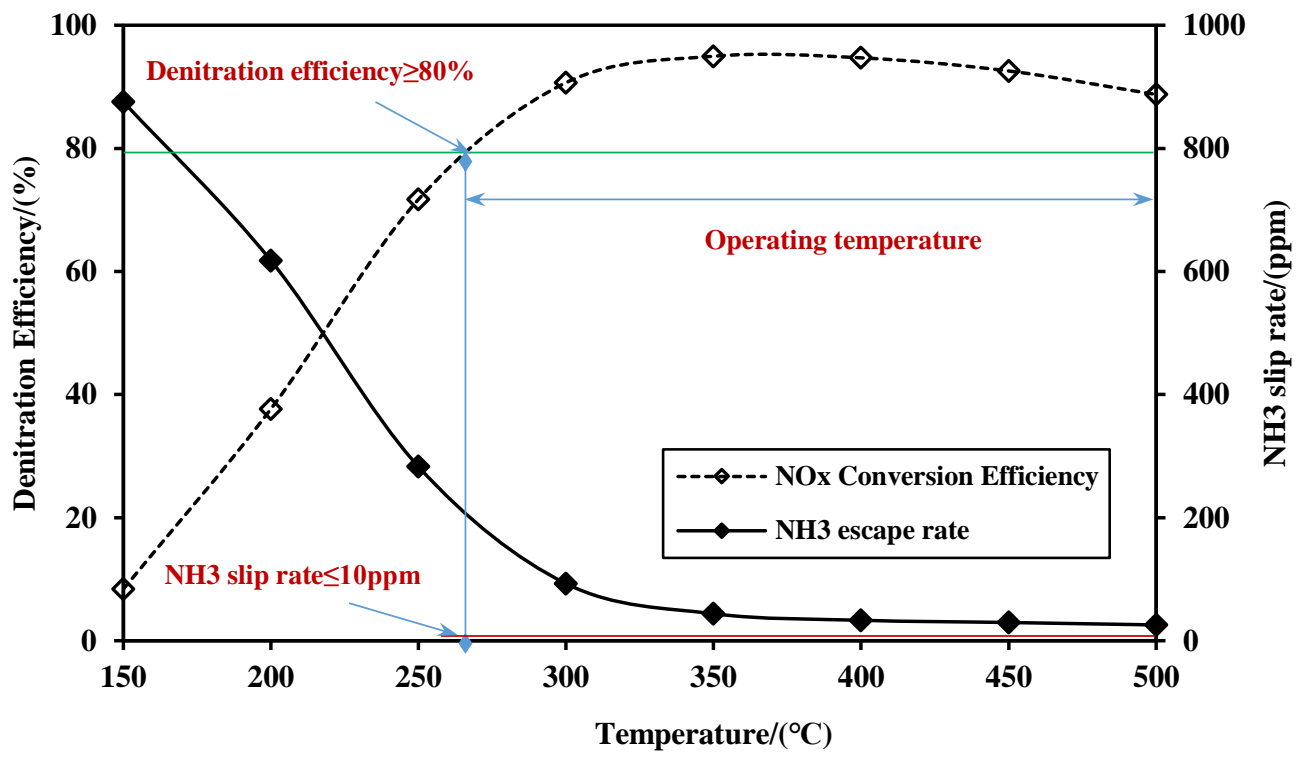

Figure 1. Effect of exhaust gas temperature on the denitration efficiency and the ammonia slip.

\subsection{Analysis of the Factors Affecting the Passivation of Ammonium Nitrate}

The influence of the reaction temperature and the $\mathrm{NO}_{2} / \mathrm{NO}_{\mathrm{x}}$ ratio on the $\mathrm{NH}_{4} \mathrm{NO}_{3}$ production and denitration efficiency were simulated in this section. According to the constructed chemical reaction model, $\mathrm{NH}_{4} \mathrm{NO}_{3}$ is easily formed at low temperatures. In addition, $\mathrm{NO}_{2}$ is the main reactant of $\mathrm{NH}_{4} \mathrm{NO}_{3}$ formation reaction and plays a great role in its formation. Therefore, considering the characteristics of $\mathrm{NH}_{4} \mathrm{NO}_{3}$ formation reaction, a speed velocity of $10,000 \mathrm{~h}^{-1}$ and a temperature range from 150 to $350{ }^{\circ} \mathrm{C}$ for the exhaust gas were adopted during the simulation. Moreover, the concentration of $\mathrm{NH}_{3}, \mathrm{O}_{2}, \mathrm{H}_{2} \mathrm{O}$, and $\mathrm{NO}_{\mathrm{x}}$ were $1000 \mathrm{ppm}, 15 \%, 3 \%$, and $1000 \mathrm{ppm}$, respectively. Furthermore, the $\mathrm{NO}_{2} / \mathrm{NO}_{\mathrm{x}}$ ratio was $0,0.05,0.10,0.15,0.20$, and 0.25 , respectively and $\mathrm{N}_{2}$ was the equilibrium gas. The simulation results are shown in Figures 2 and 3, respectively.

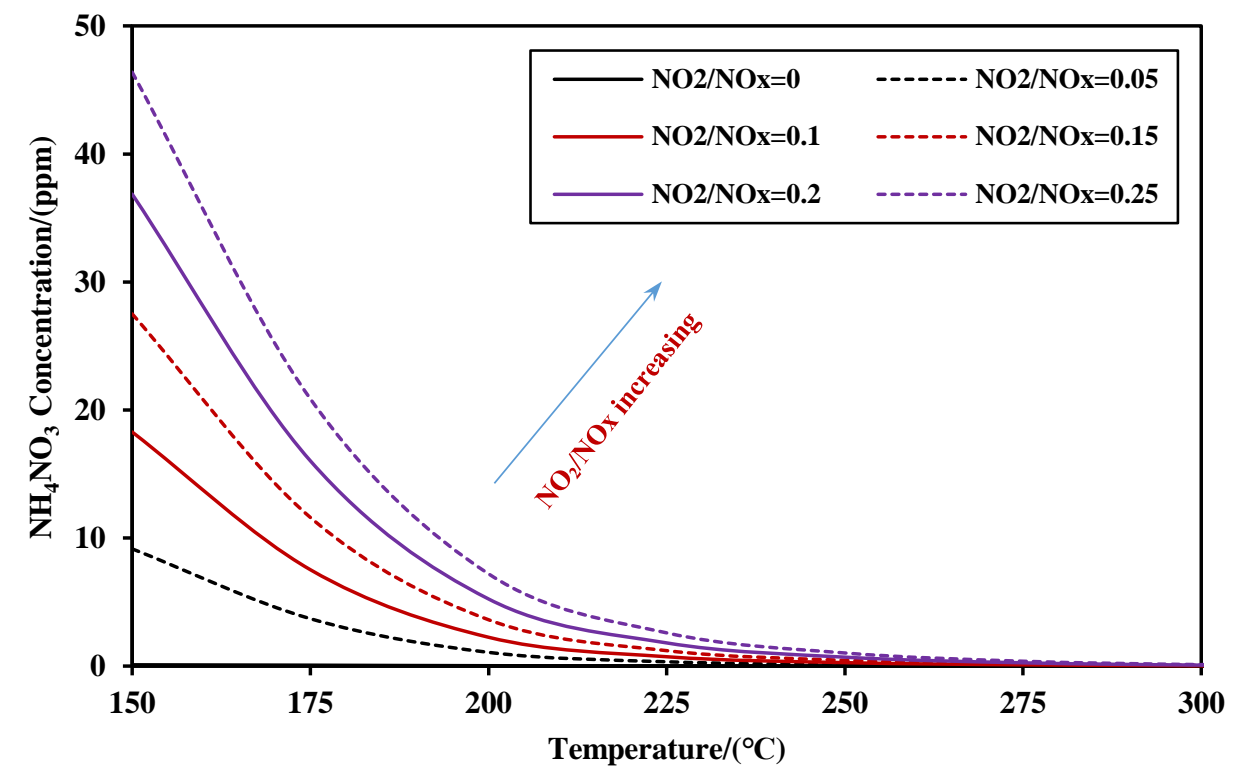

Figure 2. The influence of the reaction temperature and the $\mathrm{NO}_{2} / \mathrm{NO}_{\mathrm{x}}$ ratio on the formation of $\mathrm{NH}_{4} \mathrm{NO}_{3}$. 


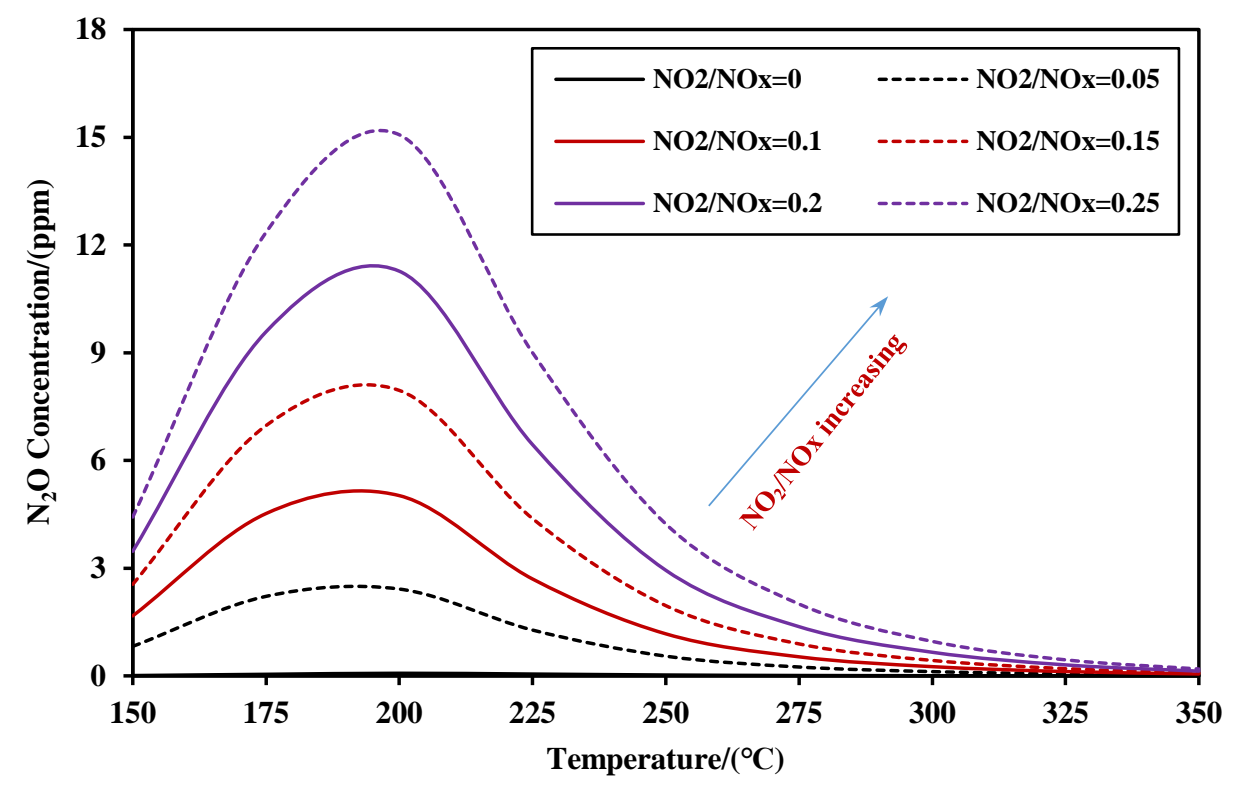

Figure 3. The influence of the reaction temperature and the $\mathrm{NO}_{2} / \mathrm{NO}_{\mathrm{x}}$ ratio on the formation of $\mathrm{N}_{2} \mathrm{O}$.

From Figure 2, as the reaction temperature increases, the amount of the formed $\mathrm{NH}_{4} \mathrm{NO}_{3}$ rapidly decreases and after $250{ }^{\circ} \mathrm{C}$, substantially no formation of $\mathrm{NH}_{4} \mathrm{NO}_{3}$ is observed. This is because $\mathrm{NH}_{4} \mathrm{NO}_{3}$ is easily decomposed at higher temperatures and its decomposition reaction is strongly dependent on the reaction temperature. In addition, the amount of $\mathrm{NH}_{4} \mathrm{NO}_{3}$ increases with the increase of the $\mathrm{NO}_{2} / \mathrm{NO}_{\mathrm{x}}$ ratio and it has a linear relationship. When the reaction temperature is higher than $250{ }^{\circ} \mathrm{C}$, the amount of $\mathrm{NH}_{4} \mathrm{NO}_{3}$ is less than $1 \mathrm{ppm}$. Conversely, at $150{ }^{\circ} \mathrm{C}$ and $0.25 \mathrm{NO}_{2} / \mathrm{NO}_{\mathrm{x}}$ ratio, the amount of $\mathrm{NH}_{4} \mathrm{NO}_{3}$ reaches a maximum value of $47 \mathrm{ppm}$.

The generated $\mathrm{NH}_{4} \mathrm{NO}_{3}$ can clog the catalyst's pores and surface, and it can also decompose into $\mathrm{N}_{2} \mathrm{O}$, which reduce the denitrification efficiency to a certain extent. As shown in Figure $3, \mathrm{~N}_{2} \mathrm{O}$ concentration is increased and then decreases with the increase of reaction temperature, but the rise of $\mathrm{NO}_{2} / \mathrm{NOx}$ ratio is conducive to the formation of $\mathrm{N}_{2} \mathrm{O}$. Conversely, at $200{ }^{\circ} \mathrm{C}$ and $0.25 \mathrm{NO}_{2} / \mathrm{NOx}$ ratio, the amount of $\mathrm{N}_{2} \mathrm{O}$ reaches a maximum value of $15 \mathrm{ppm}$.

As shown in Figure 4, the denitration efficiency increases with an increase in the $\mathrm{NO}_{2} / \mathrm{NO}_{\mathrm{x}}$ ratio and in the temperature ranging between $175^{\circ} \mathrm{C}$ and $250{ }^{\circ} \mathrm{C}$ - the former has the greatest influence on the denitration efficiency. Although increasing the $\mathrm{NO}_{2} / \mathrm{NO}_{\mathrm{x}}$ ratio can promote the progress of the denitration reaction, it is also necessary to consider the formation of a small amount of $\mathrm{NH}_{4} \mathrm{NO}_{3}$ and $\mathrm{N}_{2} \mathrm{O}$ at the low-temperature range. 


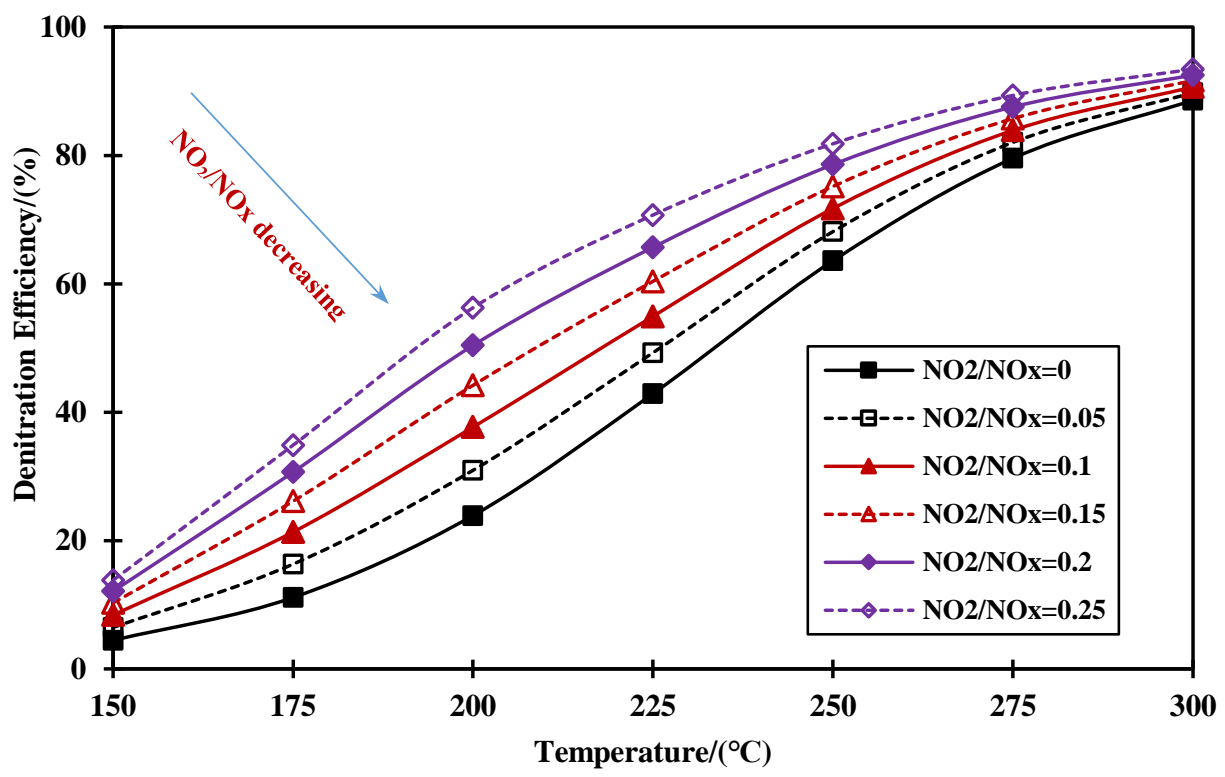

Figure 4. The influence of the reaction temperature and the $\mathrm{NO}_{2} / \mathrm{NO}_{\mathrm{x}}$ ratio on the denitration efficiency.

\subsection{Analysis of the Ammonium Nitrate Passivation Reaction Process}

In order to analyze the ammonium nitrate passivation reaction process in detail, the simulation time was set at $7000 \mathrm{~s}$. Only $\mathrm{NH}_{3}$ was introduced at the beginning and stopped at $t=5000 \mathrm{~s}$, while $\mathrm{NO}_{\mathrm{x}}$ was introduced at $t=1000 \mathrm{~s}$. According to the above section, the formation of $\mathrm{NH}_{4} \mathrm{NO}_{3}$ reaches its maximum value at $150{ }^{\circ} \mathrm{C}$ and $0.25 \mathrm{NO}_{2} / \mathrm{NOx}$ ratio. Hence, a speed velocity of $10,000 \mathrm{~h}^{-1}$ and a $\mathrm{NO}_{2} / \mathrm{NO}_{\mathrm{x}}$ ratio of 0.25 were used during the simulation. In addition, the concentration of $\mathrm{NH}_{3}, \mathrm{O}_{2}$, $\mathrm{H}_{2} \mathrm{O}$, and $\mathrm{NO}_{x}$ were $1000 \mathrm{ppm}, 15 \%, 3 \%$, and $1000 \mathrm{ppm}$, respectively. Moreover, $\mathrm{N}_{2}$ was used as the equilibrium gas. The simulation results are shown in Figure 5.

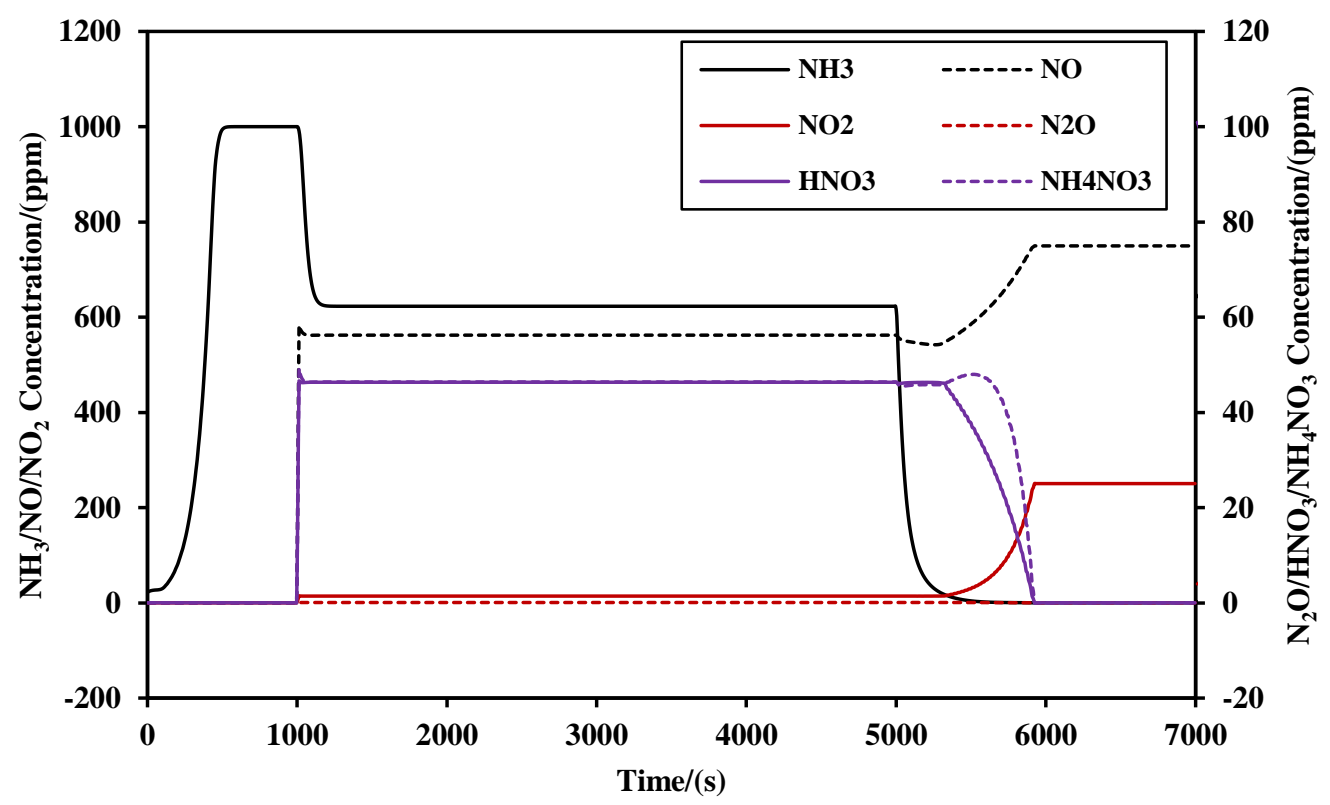

Figure 5. The relationship between the concentration of each component at the outlet of the SCR system and the change of time $\left(T=150{ }^{\circ} \mathrm{C}, \mathrm{NO}_{2} / \mathrm{NO}_{\mathrm{x}}=0.25\right)$.

Figure 5 shows the relationship between the concentration of each component at the outlet of the SCR system and the time at $T=150^{\circ} \mathrm{C}$ and $\mathrm{NO}_{2} / \mathrm{NO}_{x}$ ratio $=0.25$. Since ammonia gas was introduced at the beginning, only the adsorption and desorption reaction of ammonia gas occurred in the reactor. 
After the introduction of $\mathrm{NO}_{2}$ at $t=1000 \mathrm{~s}$, the concentration of each component began changing and when the reaction was stable, the concentration of $\mathrm{NH}_{4} \mathrm{NO}_{3}$ and $\mathrm{HNO}_{3}$ reached $46 \mathrm{ppm}$. Furthermore, no formation of $\mathrm{N}_{2} \mathrm{O}$ was seen.

In order to further analyze the $\mathrm{NH}_{4} \mathrm{NO}_{3}$ formation process, five data points $(25 \mathrm{~mm}, 375 \mathrm{~mm}$, $725 \mathrm{~mm}, 1075 \mathrm{~mm}$, and $1425 \mathrm{~mm}$, respectively) before the reactor inlet were chosen in order to obtain the variation of $\mathrm{NH}_{4} \mathrm{NO}_{3}$ formation and decomposition reaction rate of each point with the charge of time. Simulation results are shown in Figures 6 and 7, respectively.

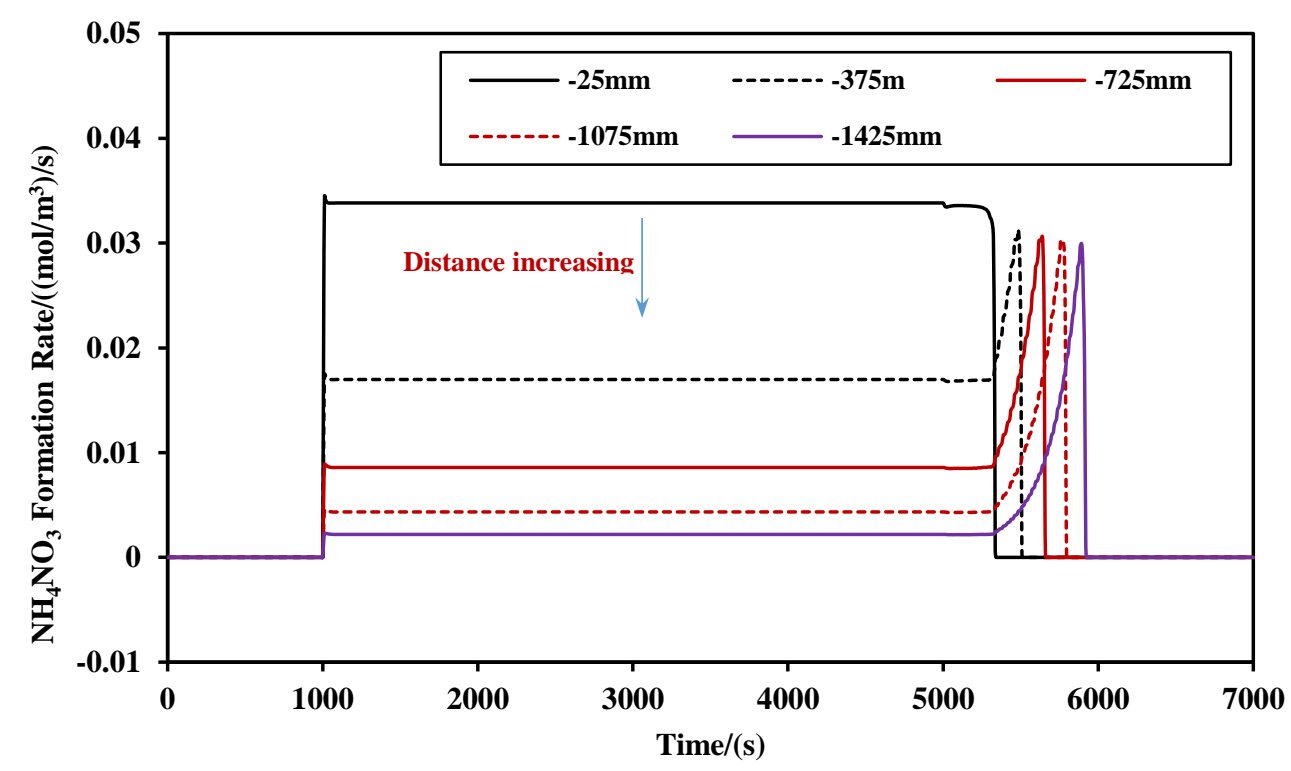

Figure 6. The relationship between the $\mathrm{NH}_{4} \mathrm{NO}_{3}$ formation reaction rate and the change of time. $\left(T=150{ }^{\circ} \mathrm{C}, \mathrm{NO}_{2} / \mathrm{NO}_{\mathrm{x}}=0.25\right)$.

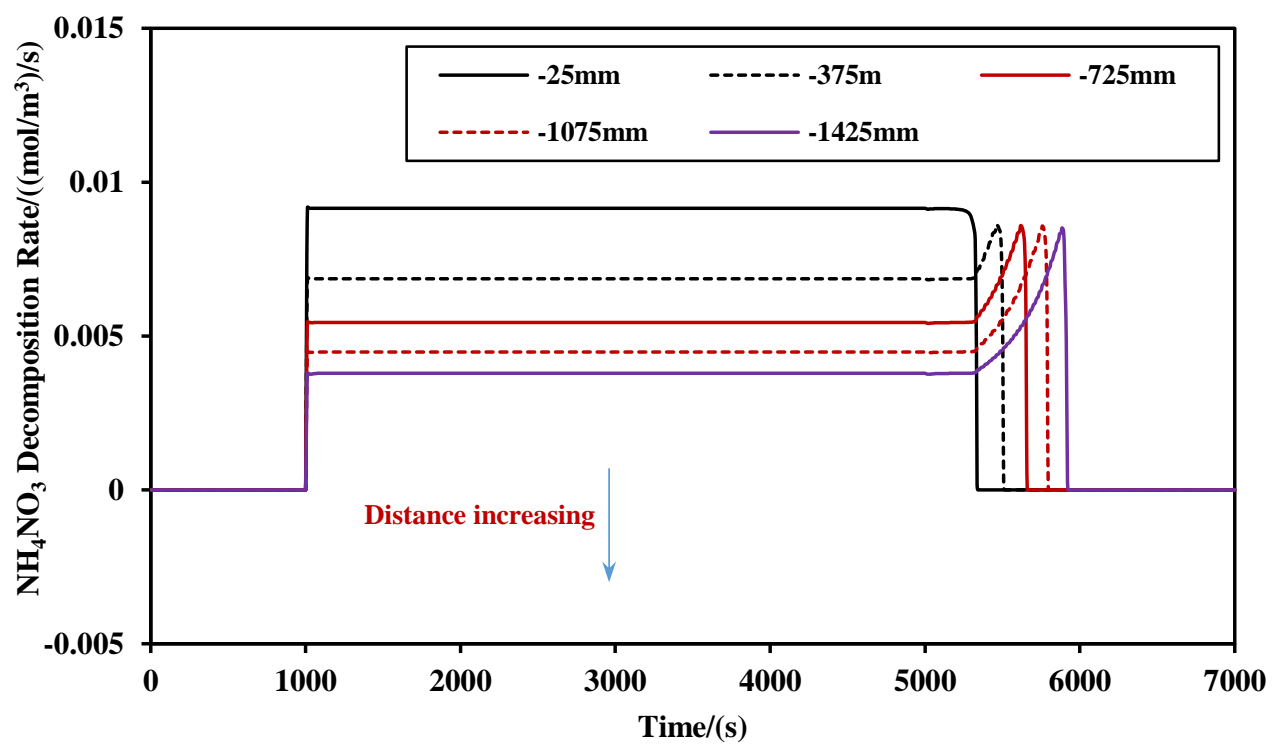

Figure 7. The relationship between the $\mathrm{NH}_{4} \mathrm{NO}_{3}$ decomposition reaction rate and the change of time. $\left(T=150{ }^{\circ} \mathrm{C}, \mathrm{NO}_{2} / \mathrm{NO}_{\mathrm{x}}=0.25\right)$.

It can be seen from Figures 6 and 7 that the formation and decomposition reaction of $\mathrm{NH}_{4} \mathrm{NO}_{3}$ starts after the introduction of $\mathrm{NO}_{\mathrm{x}}$ in the SCR reactor (at $t=1000 \mathrm{~s}$ ). After the $\mathrm{NH}_{3}$ is stopped at $t=5000 \mathrm{~s}$, the reaction continues to occur because there is still a small amount of adsorbed $\mathrm{NH}_{3}$ on the catalyst. As time passes, the $\mathrm{NH}_{3}$, which is adsorbed on the catalyst gradually decreases 
and the reaction stops. In addition, farther away from the reactor inlet, the $\mathrm{NH}_{4} \mathrm{NO}_{3}$ formation and decomposition reactions stop. This is because after the $\mathrm{NH}_{3}$ stops flowing into the reactor $(t=5000 \mathrm{~s})$, the adsorbed $\mathrm{NH}_{3}$ near the inlet is gradually consumed and the $\mathrm{NO}_{\mathrm{x}}$ concentration in the reactor increases. Moreover, by moving away from the reactor inlet, the $\mathrm{NH}_{4} \mathrm{NO}_{3}$ formation and decomposition reaction rate is increased and the adsorbed $\mathrm{NH}_{3}$ is consumed rapidly. However, the reaction stops after completion.

Figure 8 shows the relationship between the amounts of $\mathrm{NH}_{4} \mathrm{NO}_{3}$ produced before the reactor inlet and the distance (at $150{ }^{\circ} \mathrm{C}$ and $0.25 \mathrm{NO}_{2} / \mathrm{NO}_{\mathrm{x}}$ ratio). It can be seen from Figure 8 that by moving away from the reactor inlet, the amount of $\mathrm{NH}_{4} \mathrm{NO}_{3}$ is increased after reaching a maximum value of $49 \mathrm{ppm}$ at $1025 \mathrm{~mm}$ and then decreases slightly. In addition, the amount of $\mathrm{NH}_{4} \mathrm{NO}_{3}$ produced at the outlet of the SCR reactor is $47 \mathrm{ppm}$.

Figure 9 shows the relationship between the $\mathrm{NH}_{4} \mathrm{NO}_{3}$ formation and decomposition reaction rate before the reactor inlet and the distance. It can be seen from Figure 9 that the $\mathrm{NH}_{4} \mathrm{NO}_{3}$ formation and decomposition reaction rate is decreased by moving away from the reactor inlet. In addition, the $\mathrm{NH}_{4} \mathrm{NO}_{3}$ formation reaction rate is higher than the decomposition reaction rate at distance of $1025 \mathrm{~mm}$ before the SCR reactor inlet and the amount of $\mathrm{NH}_{4} \mathrm{NO}_{3}$ is continuously generated.

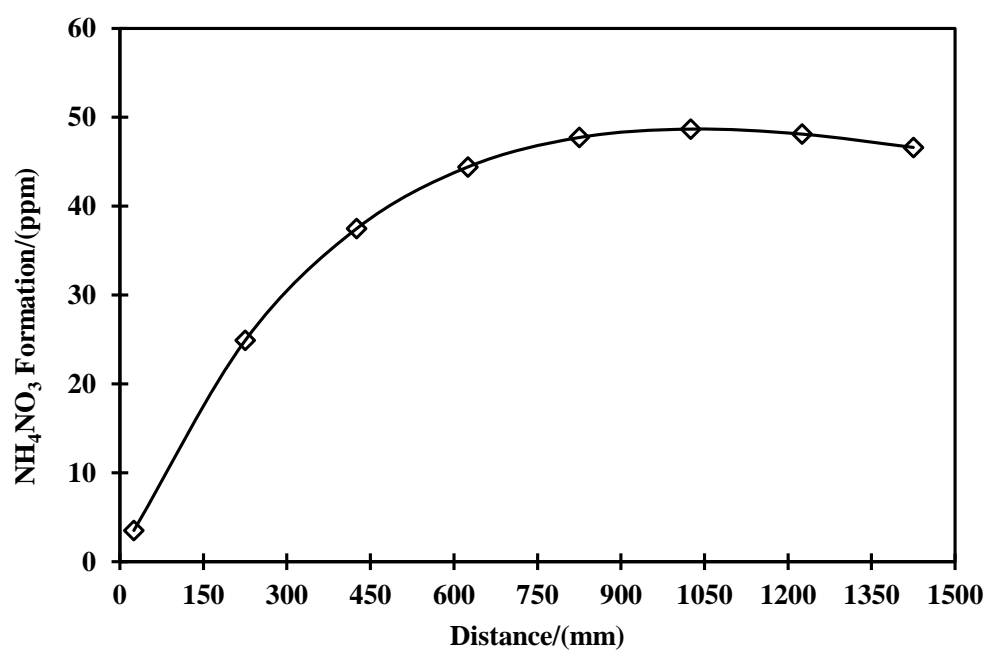

Figure 8. The relationship between the amounts of $\mathrm{NH}_{4} \mathrm{NO}_{3}$ produced before the reactor inlet and the distance $\left(\mathrm{T}=150{ }^{\circ} \mathrm{C}, \mathrm{NO}_{2} / \mathrm{NO}_{\mathrm{x}}=0.25\right)$.

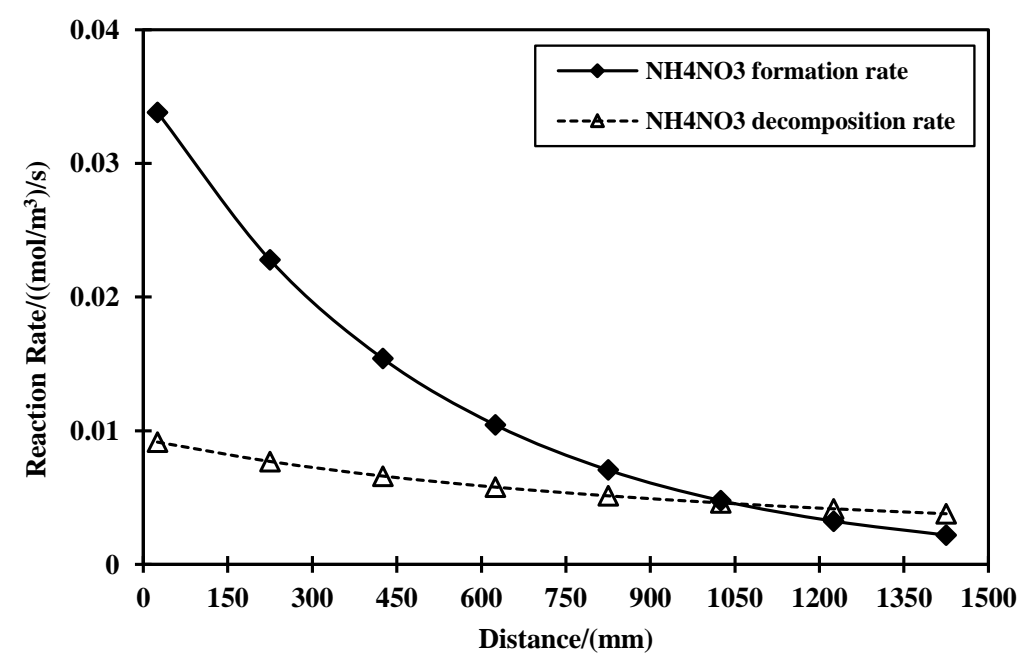

Figure 9. The relationship between the $\mathrm{NH}_{4} \mathrm{NO}_{3}$ formation and decomposition reaction rate before the reactor inlet and the distance $\left(\mathrm{T}=150^{\circ} \mathrm{C}, \mathrm{NO}_{2} / \mathrm{NOx}=0.25\right)$. 
Moreover, after $1025 \mathrm{~mm}$, the rate of decomposition reaction becomes greater than the rate of the formation reaction and the amount of $\mathrm{NH}_{4} \mathrm{NO}_{3}$ is slightly decreased.

\subsection{Analysis of the Factors Affecting the Sulfate Passivation}

According to the model of the sulfate passivation reaction, the sulfate was mainly formed by the reaction of $\mathrm{SO}_{3}, \mathrm{H}_{2} \mathrm{O}$, and the adsorbed $\mathrm{NH}_{3}$. In addition, $\mathrm{SO}_{3}$ was formed by the oxidation of $\mathrm{SO}_{2}$. Therefore, this section studies the effect of $\mathrm{SO}_{2}, \mathrm{O}_{2}$, and $\mathrm{H}_{2} \mathrm{O}$ concentrations on the sulfate formation. The exhaust gas components concentrations that were used during the simulation are shown in Table 2 .

Table 2. The exhaust gas components concentrations.

\begin{tabular}{cc}
\hline Exhaust Gas & Concentration \\
\hline $\mathrm{SO}_{2}(\mathrm{ppm})$ & $100,300,500,700,1000$ \\
$\mathrm{O}_{2}(\%)$ & $5,10,15,16$ \\
$\mathrm{H}_{2} \mathrm{O}(\%)$ & $1,3,5,10$ \\
$\mathrm{NH}_{3}(\mathrm{ppm})$ & 1000 \\
$\mathrm{NO}(\mathrm{ppm})$ & 1000 \\
\hline
\end{tabular}

In addition, the exhaust speed velocity was $10,000 \mathrm{~h}^{-1}$ and the exhaust gas temperature increased from 50 to $500{ }^{\circ} \mathrm{C}$ at a rate of $10^{\circ} \mathrm{C} / \mathrm{min}$. The simulation results are shown in Figures $10-13$, respectively.

Figure 10 shows the relationship between the denitration efficiency and the $\mathrm{SO}_{2}$ concentration at different temperatures. It can be seen from Figure 10 that the denitration efficiency decreases with the increase of the $\mathrm{SO}_{2}$ concentration. Moreover, at $250{ }^{\circ} \mathrm{C}$, a significant decline in the SCR denitration efficiency of $38 \%$ is observed as the $\mathrm{SO}_{2}$ concentration changes from 100 to $1000 \mathrm{ppm}$. However, the difference between the SCR denitration efficiencies decrease as the temperature increases, irrespective of the $\mathrm{SO}_{2}$ concentrations - both at the starting temperatures and the final temperatures. Likewise, when the temperature reaches $325^{\circ} \mathrm{C}$, the denitration efficiency is only $6 \%$ under the conditions of $100 \mathrm{ppm}$ and $1000 \mathrm{ppm}$ of $\mathrm{SO}_{2}$ concentration.

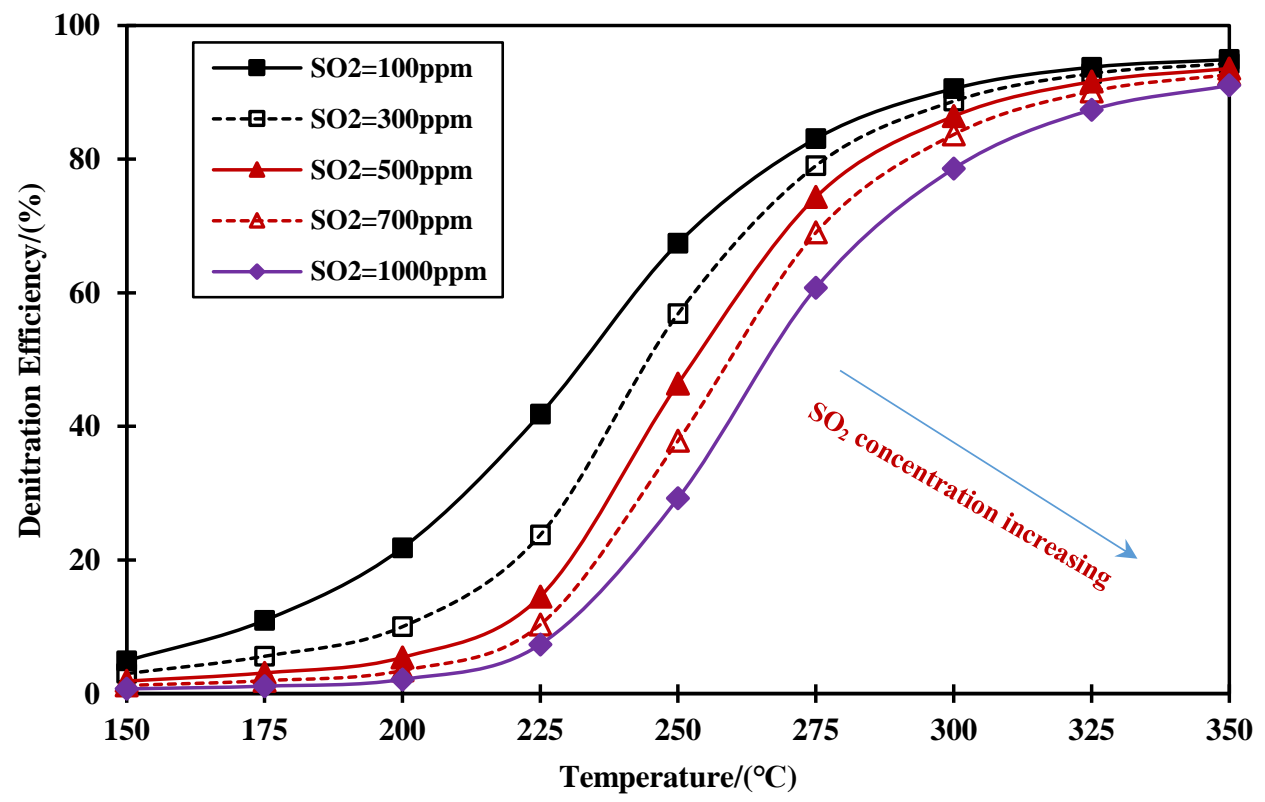

Figure 10. The relationship between the denitration efficiency and the $\mathrm{SO}_{2}$ concentration at different temperatures $\left(\mathrm{O}_{2}: 16 \%, \mathrm{H}_{2} \mathrm{O}: 3 \%\right)$.

Since part of the $\mathrm{SO}_{2}$ entering the SCR catalyst channel is adsorbed on the catalyst surface or reacted with the adsorbed $\mathrm{NH}_{3}$ to form sulfate, the sulfur content of the exhaust gases at the inlet 
and the outlet of the reactor is not balanced. Therefore, the equilibrium concentration of sulfur in the passivation reaction is the total amount of the sulfur at the inlet minus the total amount of the sulfur at the outlet, as shown below:

$$
\mathrm{C}_{\mathrm{S} \text {-bal }}=\mathrm{C}_{\mathrm{SO}_{2 \text { in }}}-\mathrm{C}_{\mathrm{SO}_{2 \text { out }}}-\mathrm{C}_{\mathrm{SO}_{3 \text { out }}}
$$

According to the sulfur equilibrium concentration formula, the sulfur equilibrium concentration represents the total amount of residual sulfur in the SCR reactor, which equals the total amount of the adsorbed $\mathrm{SO}_{2}$ and the sulfate produced.

Figure 11 shows the relationship between the sulfur equilibrium concentration and the temperature at different $\mathrm{SO}_{2}$ concentrations. It can be seen from Figure 11 that the larger the $\mathrm{SO}_{2}$ concentration at the inlet of the reactor, the more the change in the sulfur equilibrium concentration. In addition, before $270{ }^{\circ} \mathrm{C}$, the sulfur equilibrium concentration is positive and rises with the increase of the temperature, which can be seen at the different $\mathrm{SO}_{2}$ concentrations. Moreover, the peaks appear around $250{ }^{\circ} \mathrm{C}$ and their values increase with the increase of the $\mathrm{SO}_{2}$ concentration. Furthermore, when the temperature is between 270 and $350{ }^{\circ} \mathrm{C}$, the sulfur equilibrium concentration is negative and the peak-peak is at around $290^{\circ} \mathrm{C}$ with its value decreasing by an increase of the $\mathrm{SO}_{2}$ concentration. However, when the temperature reaches $350{ }^{\circ} \mathrm{C}$, the sulfur equilibrium concentration is reduced to about zero, which means that the sulfur element is balanced at the inlet and the outlet of the reactor.

Therefore, at exhaust gas temperature lower than $270{ }^{\circ} \mathrm{C}$, there is sulfate formation in the reactor and a small amount of the adsorbed $\mathrm{SO}_{2}$ exists. When the exhaust gas temperature is lower than 350 ${ }^{\circ} \mathrm{C}$, the deposited sulfate in the reactor is decomposed to generate $\mathrm{SO}_{2}$ and the sulfur is exported. Thus, the total amount of elements is greater than the total amount of sulfur in the inlet and the equilibrium concentration of sulfur is negative. Furthermore, when the temperature of the exhaust gas is greater than $350{ }^{\circ} \mathrm{C}$, no more sulfate is formed but a small amount of the adsorbed $\mathrm{SO}_{2}$ is still present and the equilibrium concentration of sulfur is slightly greater than zero.

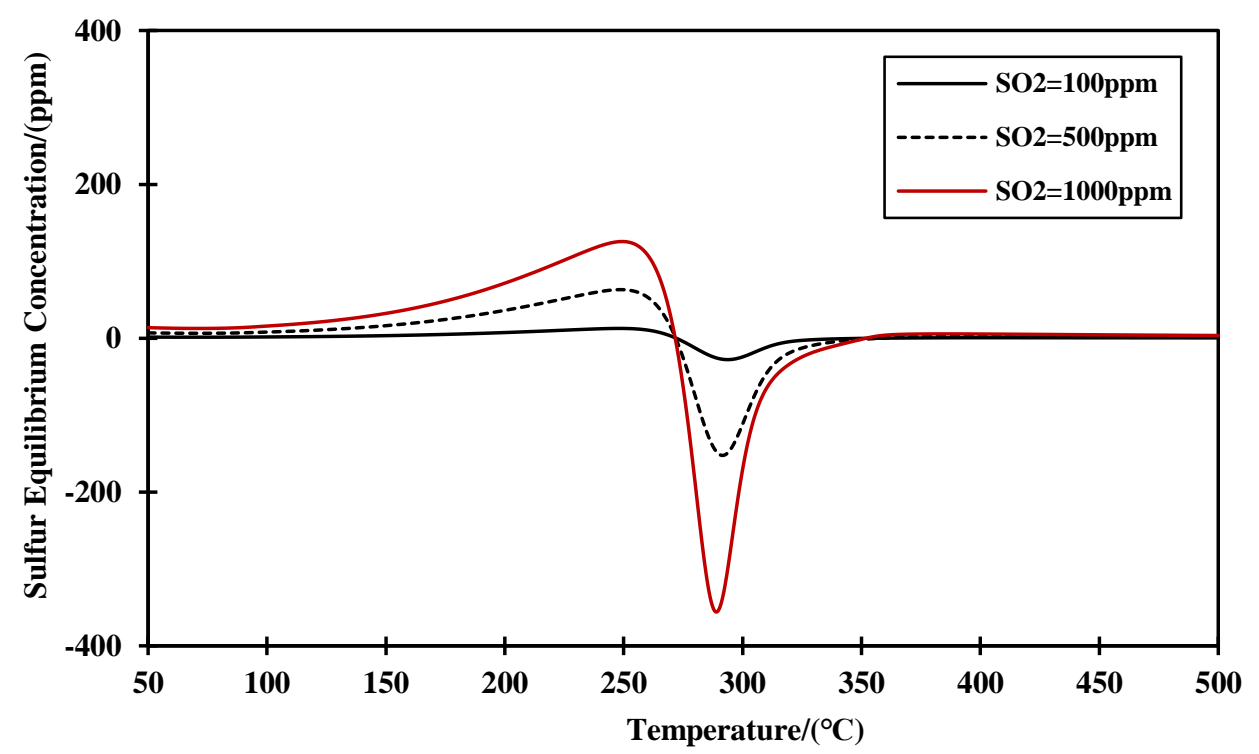

Figure 11. The relationship between the sulfur equilibrium concentration and the temperature at different $\mathrm{SO}_{2}$ concentrations $\left(\mathrm{O}_{2}: 16 \%, \mathrm{H}_{2} \mathrm{O}: 3 \%\right)$.

Figure 12 shows the relationship between the equilibrium concentration of sulfur and the temperature at different $\mathrm{O}_{2}$ concentrations. From Figure 12, the equilibrium concentration of sulfur increases with an increase in the concentration of $\mathrm{O}_{2}$. In addition, the maximum and minimum values appear at $15 \% \mathrm{O}_{2}$ and these values are $62 \mathrm{ppm}$ and $-154 \mathrm{ppm}$, respectively. 


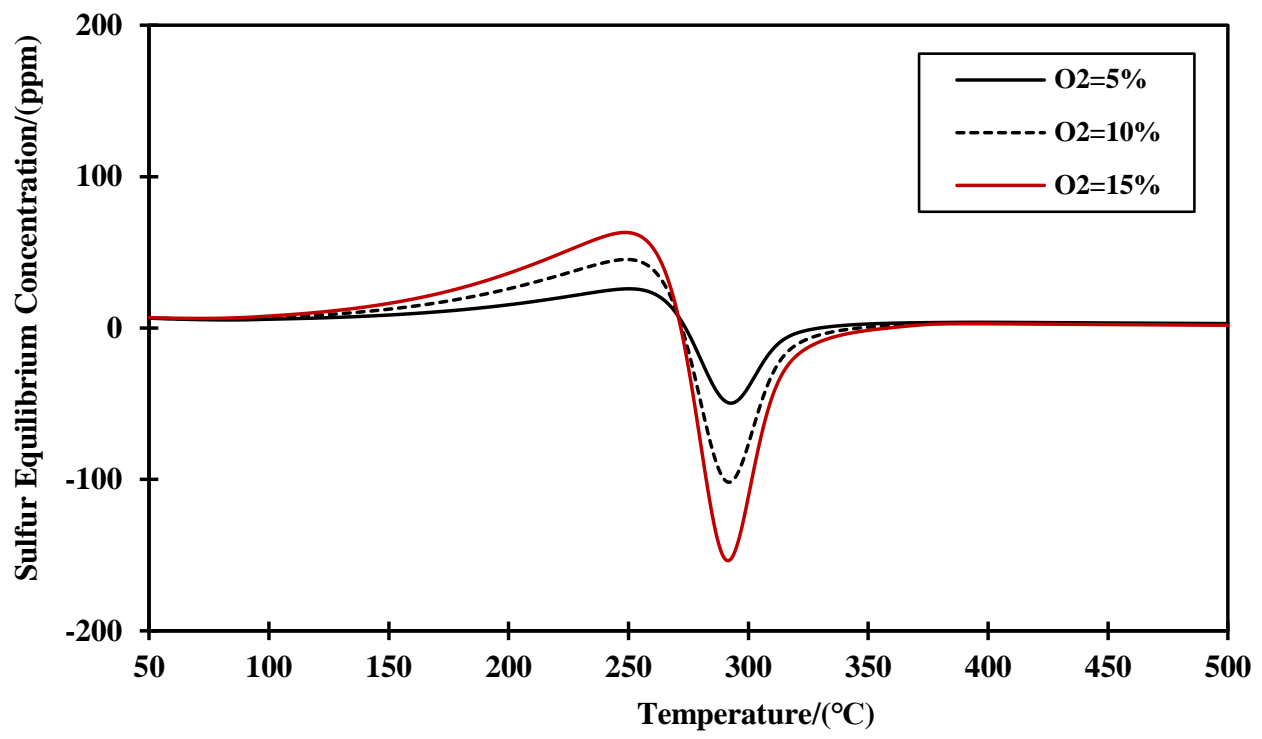

Figure 12. The relationship between the equilibrium concentration of sulfur and the temperature at different $\mathrm{O}_{2}$ concentrations $\left(\mathrm{SO}_{2}: 500 \mathrm{ppm}, \mathrm{H}_{2} \mathrm{O}: 3 \%\right)$.

Figure 13 shows the relationship between the equilibrium concentration of sulfur and the temperature at different $\mathrm{H}_{2} \mathrm{O}$ concentrations. It can be seen from Figure 13 that the peak value of the sulfur equilibrium concentration is $65 \mathrm{ppm}$ and $59 \mathrm{ppm}$ at $10 \%$ and $1 \%$ of the $\mathrm{H}_{2} \mathrm{O}$ concentrations, respectively, that differs by $6 \mathrm{ppm}$. This indicates that the change in $\mathrm{H}_{2} \mathrm{O}$ concentration has less effect on the equilibrium concentration of sulfur. Thus, the change in $\mathrm{H}_{2} \mathrm{O}$ concentration has minimal impact on the formation of sulfate.

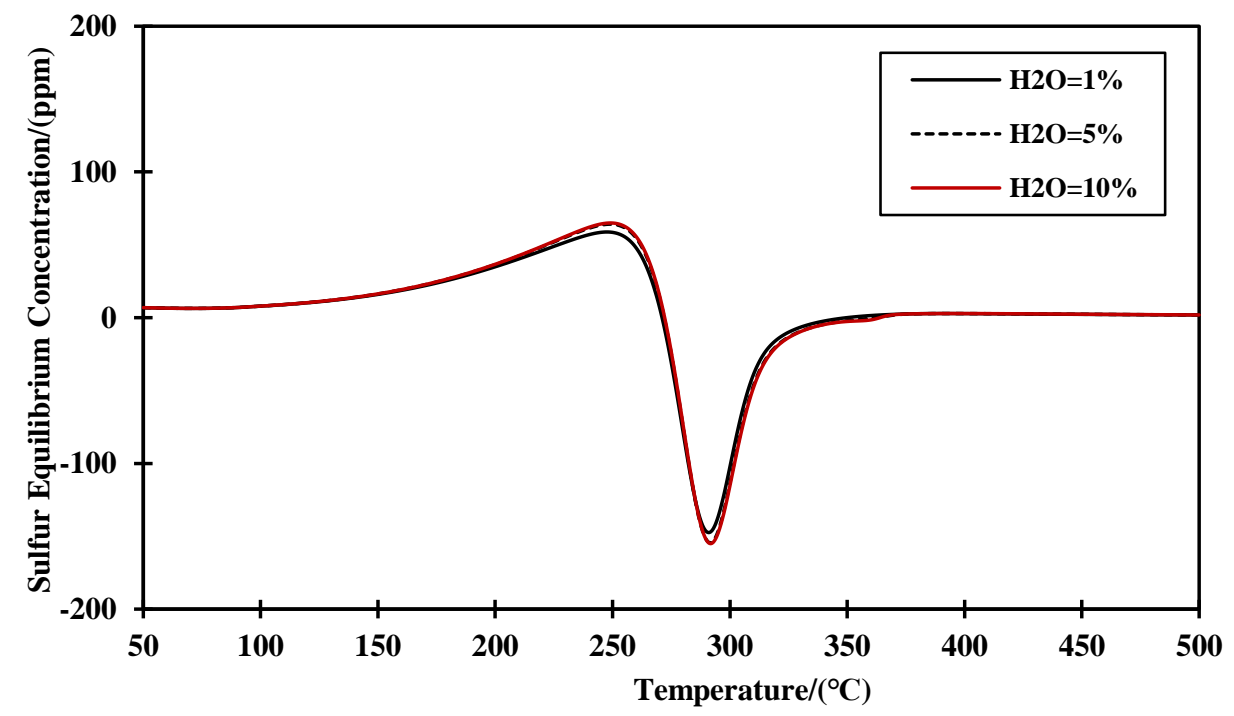

Figure 13. The relationship between the equilibrium concentration of sulfur and the temperature at different $\mathrm{H}_{2} \mathrm{O}$ concentrations ( $\left.\mathrm{SO}_{2}: 500 \mathrm{ppm}, \mathrm{O}_{2}: 15 \%\right)$.

\subsection{Analysis of the Passivation Reaction Process of Ammonium Sulfate}

This section analyzes the passivation reaction process of ammonium sulfate. During the simulation, the concentration of $\mathrm{NH}_{3}, \mathrm{NO}, \mathrm{O}_{2}, \mathrm{H}_{2} \mathrm{O}$, and $\mathrm{SO}_{2}$ were $1000 \mathrm{ppm}, 1000 \mathrm{ppm}, 15 \%, 3 \%$, and $500 \mathrm{ppm}$, respectively. In addition, an exhaust speed velocity of $10,000 \mathrm{~h}^{-1}$ and exhaust gas temperature range from 150 to $500{ }^{\circ} \mathrm{C}$ were used. Moreover, the nitrogen $\left(\mathrm{N}_{2}\right)$ was used as the balance gas. Among them, from $t=0$ to $t=2 \mathrm{~h}$, the $\mathrm{SO}_{2}$ reaction in the exhaust gas did not reach equilibrium 
and during the time from $t=2$ to $t=30 \mathrm{~h}, \mathrm{SO}_{2}$ was introduced. The simulation results are shown in Figures 14 and 15, respectively.

Figure 14 shows the relationship between the denitration efficiency and the temperature at different reaction times. As shown in Figure 14, after 30 hours of operation, the denitration efficiency at each temperature is reduced. In addition, a maximum decline in the denitration efficiency occurs at $225^{\circ} \mathrm{C}$, as the reaction times change from 0 to 30 hours, and decrease gradually with the increase of the temperature. Moreover, for exhaust gas temperatures higher than $300{ }^{\circ} \mathrm{C}$, the effect of the $\mathrm{SO}_{2}$ concentration on the denitration efficiency is small and the denitration efficiency is above $85 \%$. This indicates that the catalyst has a stronger sulfur resistance when the exhaust gas temperature is higher than $325^{\circ} \mathrm{C}$.

Figure 15 shows the variation of denitration efficiency with time at sulfur-containing exhaust gas conditions. From Figure 15, after the introduction of $\mathrm{SO}_{2}$ into the reactor, the denitration efficiency decreases with time when the exhaust gas temperature is lower than $300^{\circ} \mathrm{C}$. Contrariwise, when the exhaust gas temperature is higher than $350^{\circ} \mathrm{C}$, the denitration efficiency does not change substantially. Furthermore, when the exhaust gas temperature is $200^{\circ} \mathrm{C}$ and $250{ }^{\circ} \mathrm{C}$, the introduction of $\mathrm{SO}_{2}$ greatly influences the catalyst activity and the denitration efficiency, which decreases by $26 \%$ and $25 \%$, respectively, after $t=30 \mathrm{~h}$. This indicates that the catalyst sulfate passivation is more serious at lower exhaust gas temperatures and $\mathrm{SO}_{2}$ has a little impact on the catalyst activity when the exhaust gas temperature is higher than $300{ }^{\circ} \mathrm{C}$.

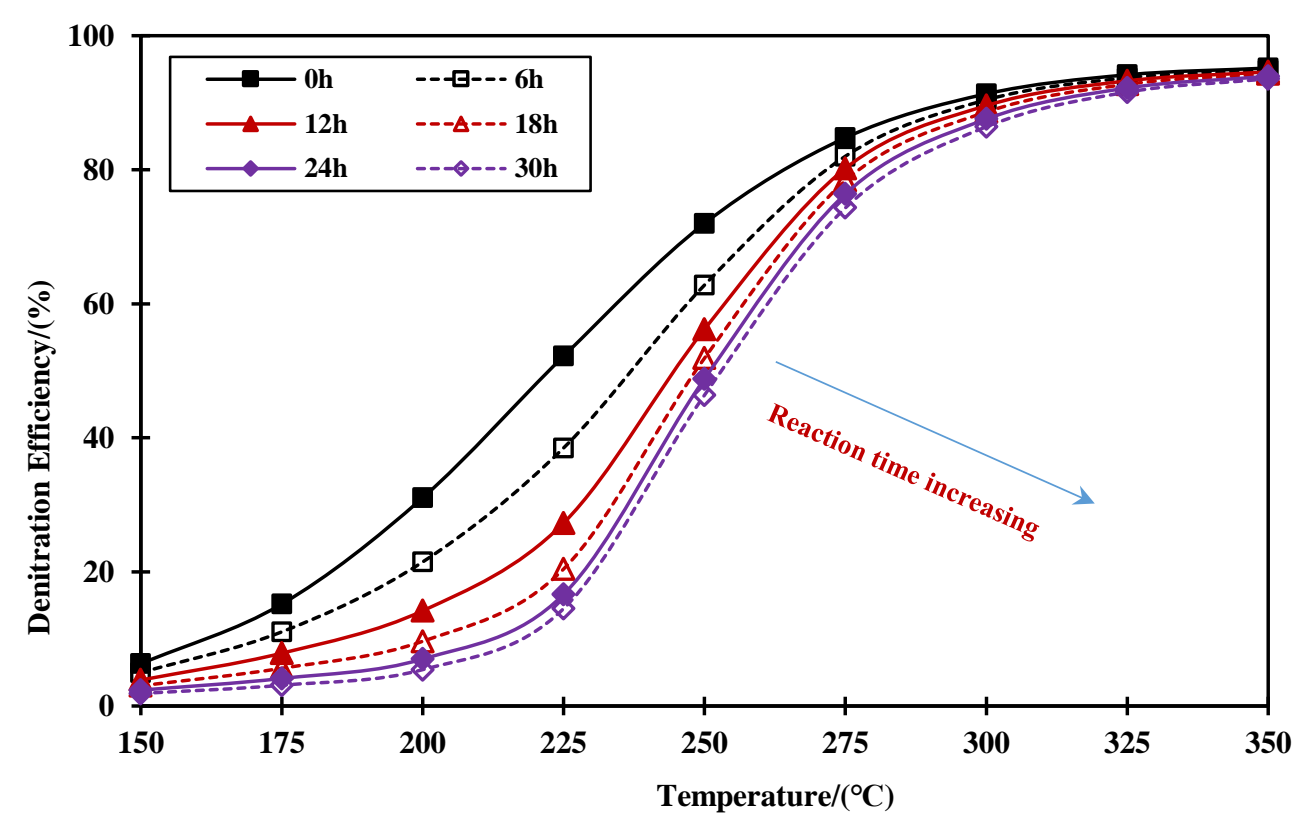

Figure 14. The relationship between the denitration efficiency and the exhaust gas temperature with different reaction times. 


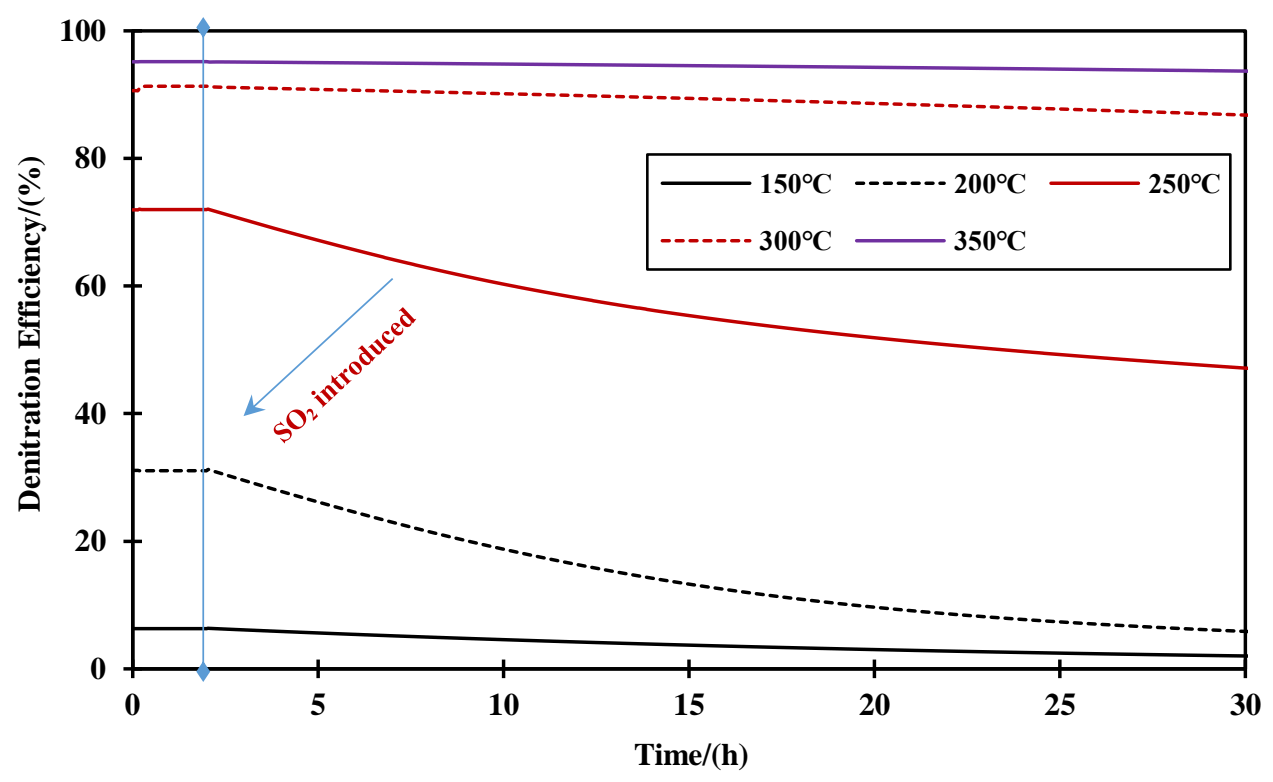

Figure 15. The variation law of the denitration efficiency with time under the condition of sulfur-containing exhaust gas.

\section{Classification of the Marine Selective Catalytic Reduction (SCR) System}

Compared with vehicle diesel engines, the marine diesel engine's SCR system is divided into a high-pressure SCR system (HP-SCR) located in front of the turbine and a low-pressure SCR system (LP-SCR) placed at the back [3], which are shown in the Figure 16. Since the exhaust gas in the exhaust pipe drives the turbine to work, the temperature of the exhaust gas before and after the turbine differs by $50 \sim 175^{\circ} \mathrm{C}$ - so the high-pressure SCR system in front of the turbine can make full use of the higher exhaust gas temperature and also improve its activity. At the same time, the high-pressure SCR system has a high working pressure, and its absolute pressure is several times higher than the low-pressure SCR system, which is equivalent to reducing the volume flow rate or linear velocity of the treated exhaust gases and increasing the SCR reaction time. Therefore, under the same design requirements, the high-pressure SCR system has a more compact structure and higher efficiency making it more suitable for the high-power low-speed diesel engines.

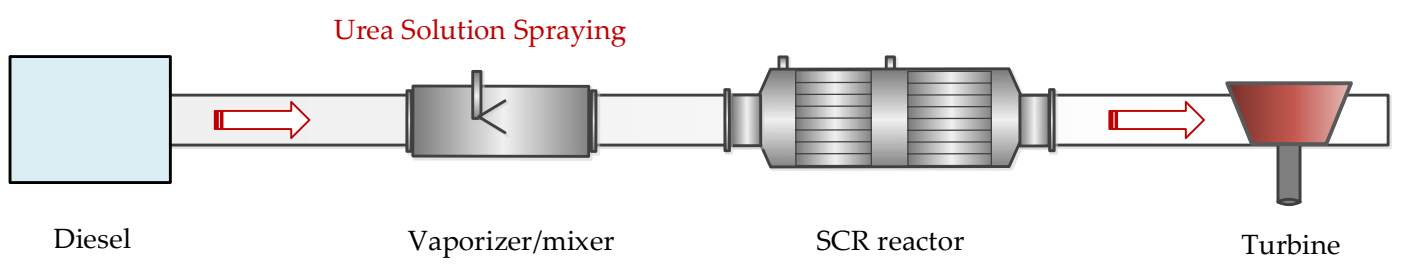

(1) HP-SCR.

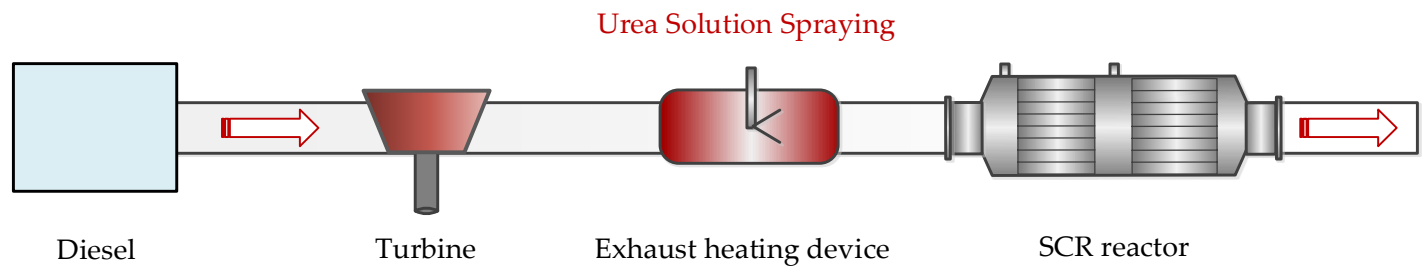

(2) LP-SCR.

Figure 16. Schematic diagram of the marine diesel engine high-pressure SCR system and low-pressure SCR system. 
Similar to vehicle SCR systems, honeycomb or plate $\mathrm{V}_{2} \mathrm{O}_{5} / \mathrm{TiO}_{2}$ type catalysts are often used in marine SCR systems. These kinds of catalysts have a porous structure with extremely large internal surface area and a large number of active centers on the surface, which are necessary for catalytic reactions [23]. When the diesel engine is working normally, urea solution is sprayed upstream of the SCR reactor or the catalyst and because of the high temperature of the exhaust gas, urea solution can be both vaporized and atomized. Moreover, urea pyrolysis reaction and isocyanic acid hydrolysis reaction will result in the formation of $\mathrm{NH}_{3}$ and $\mathrm{CO}_{2}$.

Urea pyrolysis reaction:

$$
\mathrm{CO}\left(\mathrm{NH}_{2}\right)_{2}(\mathrm{l}) \rightarrow \mathrm{HNCO}(\mathrm{g})+\mathrm{NH}_{3}(\mathrm{~g})
$$

Hydrolytic reaction of isocyanic acid:

$$
\mathrm{HNCO}(\mathrm{g})+\mathrm{H}_{2} \mathrm{O}(\mathrm{g}) \rightarrow \mathrm{NH}_{3}(\mathrm{~g})+\mathrm{CO}_{2}(\mathrm{~g})
$$

The reducing agent $\mathrm{NH}_{3}$ will then mix with $\mathrm{NO}$ and $\mathrm{NO}_{2}$ in the exhaust gas causing the following reactions to occur in the catalyst [6-8].

Standard SCR reaction:

$$
4 \mathrm{NH}_{3}(\mathrm{~g})+4 \mathrm{NO}(\mathrm{g})+\mathrm{O}_{2}(\mathrm{~g}) \rightarrow 4 \mathrm{~N}_{2}(\mathrm{~g})+6 \mathrm{H}_{2} \mathrm{O}(\mathrm{g})
$$

Fast SCR reaction:

$$
4 \mathrm{NH}_{3}(\mathrm{~g})+2 \mathrm{NO}(\mathrm{g})+2 \mathrm{NO}_{2}(\mathrm{~g}) \rightarrow 4 \mathrm{~N}_{2}(\mathrm{~g})+6 \mathrm{H}_{2} \mathrm{O}(\mathrm{g})
$$

Slow SCR reaction:

$$
8 \mathrm{NH}_{3}(\mathrm{~g})+6 \mathrm{NO}_{2}(\mathrm{~g}) \rightarrow 7 \mathrm{~N}_{2}(\mathrm{~g})+12 \mathrm{H}_{2} \mathrm{O}(\mathrm{g})
$$

As the exhaust gas temperature of the marine diesel engine is low and contains a lot of SOx, the catalyst will have some side reactions that will mainly include the formation reaction of ammonium salts such as sulfate and nitrate, respectively [12-18].

$$
\begin{gathered}
2 \mathrm{NH}_{3}(\mathrm{~g})+2 \mathrm{NO}_{2}(\mathrm{~g}) \rightarrow \mathrm{N}_{2}(\mathrm{~g})+\mathrm{NH}_{4} \mathrm{NO}_{3}(\mathrm{~s})+\mathrm{H}_{2} \mathrm{O}(\mathrm{g}) \\
\mathrm{SO}_{3}(\mathrm{~g})+\mathrm{H}_{2} \mathrm{O}(\mathrm{g})+\mathrm{NH}_{3}(\mathrm{~g}) \rightarrow \mathrm{NH}_{4} \mathrm{HSO}_{4}(\mathrm{~s})
\end{gathered}
$$

According to the chemical formulas, the product of ammonium salt will consume a certain amount of reducing agent resulting in a waste of the reducing agent. In addition, hygroscopicity of the ammonium salt can cause corrosion of the exhaust pipe. Furthermore, the deposition on the surface and the pore channels of the catalyst will further reduce its activity. However, these reactions are reversible under certain conditions.

\section{Marine SCR System Simulation Model}

The high-pressure SCR system of a low-speed marine diesel engine was adopted as the research object in this paper and a one-dimensional steady-state simulation model of this system was constructed using the GT-power software, as shown in Figure 17. When the diesel engine works in a stable manner, the pressure in the intake and the exhaust pipes is small, which is considered a constant. In addition, to calculate the steady state of the exhaust system, the volumetric method can be used under the following assumptions [24]:

1. Ignoring the propagation, reflection, and superposition of the pressure waves along the exhaust gas pipe. 
2. Simplifying the unsteady flow in the exhaust gas pipe to a quasi-stable flow, which can be justified by the fact that for a sufficiently small step length, the state parameters of the intake pipe will change only with time.

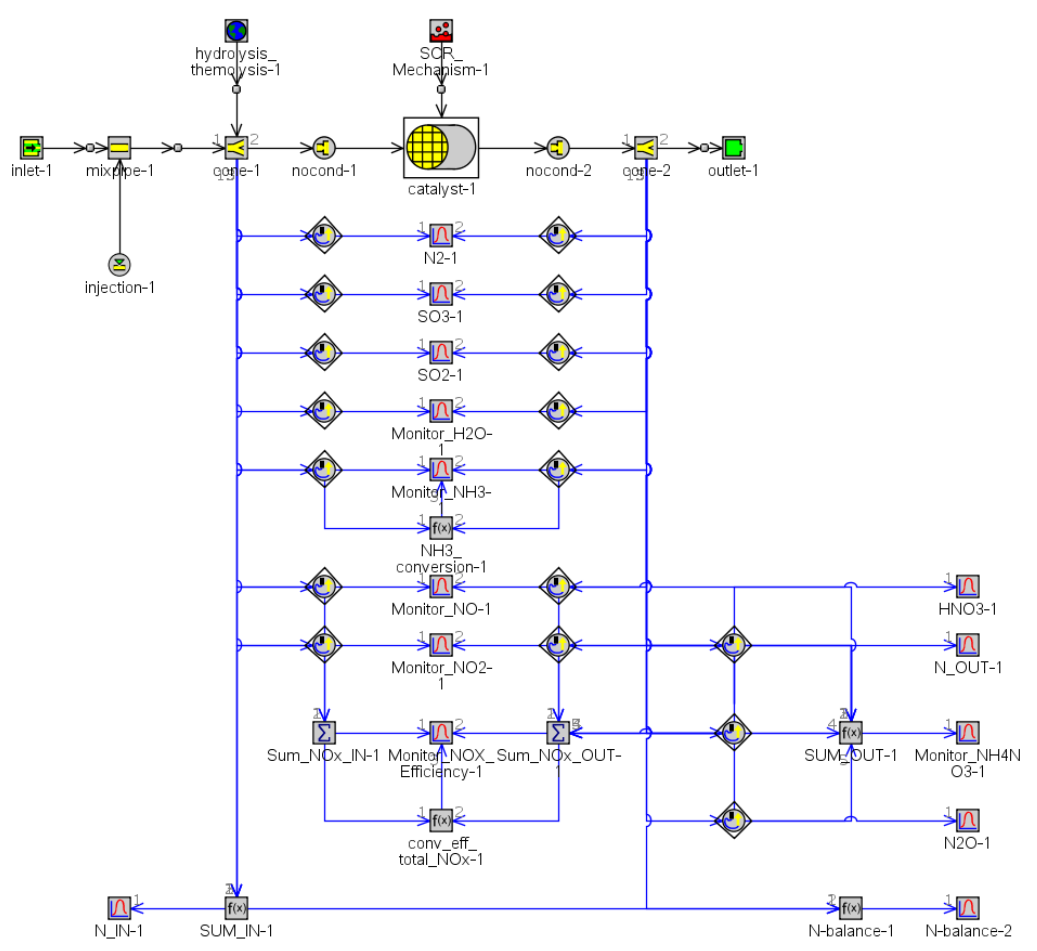

Figure 17. SCR system simulation model.

The volume of the exhaust system consists the volume of the exhaust pipe, the mixer pipe, and the SCR reactor, respectively. The exhaust gas enters the exhaust pipe and flows through the mixer to the SCR reactor. Since the process of urea spray atomization and denitrification is involved in the SCR system, the quality and composition of the flow changes, and the source term has to be introduced into both its mass and energy equations. Meanwhile, the radial diffusion of components was ignored in the SCR reactor and the catalyst was assumed to be a porous medium. In addition, the mass and momentum conservation equation, the gas and solid energy conservation equation, and the component transport equation were constructed [24].

The reversible and irreversible reactions in the SCR system can be divided into two types: the gas-phase reaction and the surface reaction. During the calculation, the forward reaction rate constant is solved according to the Arrhenius law, which is determined by the pre-exponential factor, the temperature coefficient, and the activation energy. For reversible reactions, the reverse reaction rate is determined by the forward reaction rate constant and the chemical equilibrium constant [24]. Regarding surface reactions, it is assumed that the reactants are adsorbed on the surface of the solid catalyst and then formed on an activated intermediate compound with another reactant in the gas phase to obtain the final product. Since the surface reaction is a chemical reaction control step, the overall reaction rate is proportional to the coverage of the adsorbent material on the surface of the catalyst and the partial pressure of the gas phase.

Under the condition of the marine diesel engine exhaust gas, the formation reaction of ammonium salts such as nitrate and sulfate are inevitable in the SCR reaction process. They are deposited on both the surface and the pore channels of the catalyst, which reduces its activity. This is the reason why those reactions are be classified as the ammonium salt passivation reactions. In the SCR denitration reaction model, the nitrate and the sulfate passivation reaction models were embedded in this paper to simulate the formation process and the influence factors of the sulfate and the nitrate. 


\subsection{Urea Decomposition and Denitrification Reaction Model}

The process of urea decomposition mainly includes water evaporation, urea decomposition by heat, isocyanic acid hydrolysis, and other polymerization reactions. When the exhaust gas temperature is low (less than $190^{\circ} \mathrm{C}$ ), the urea droplets that are stuck to the inner wall of the tube wall polymerize the biuret, the cyanuric acid, and the other polymers as well [25]. These polymers accumulate to form other sediments, and even block the nozzles and the channels of the catalyst.

Since the marine diesel engine exhaust gas temperature is required to be higher than $170{ }^{\circ} \mathrm{C}$ (acid dew point), the side reactions such as the polymerization in the urea decomposition process can be ignored. Therefore, the process of urea decomposition is simplified to the urea pyrolysis reaction and the $\mathrm{HNCO}$ hydrolysis reaction. In addition, the final products are $\mathrm{NH}_{3}$ and $\mathrm{CO}_{2}$ and the reaction pathway can be simplified to a 2-step gas reaction [26,27], as shown in Table 3.

Table 3. SCR reaction pathway and reaction rate.

\begin{tabular}{cccc}
\hline No. & Reaction Formula & Pre-Exponential Factor & $\begin{array}{c}\text { Activation Energy Ea } \\
\text { (J/kmol) }\end{array}$ \\
\hline $\mathrm{R} 1$ & $\mathrm{CO}\left(\mathrm{NH}_{2}\right)_{2}(\mathrm{l}) \rightarrow \mathrm{HNCO}(\mathrm{g})+\mathrm{NH}_{3}(\mathrm{~g})$ & $4.9 \times 10^{3}$ & $2.3 \times 10^{7}$ \\
$\mathrm{R} 2$ & $\mathrm{HNCO}(\mathrm{g})+\mathrm{H}_{2} \mathrm{O}(\mathrm{g}) \rightarrow \mathrm{NH}_{3}(\mathrm{~g})+\mathrm{CO}_{2}(\mathrm{~g})$ & $2.3 \times 10^{5}$ & $6.2 \times 10^{7}$ \\
\hline
\end{tabular}

The $\mathrm{NH}_{3}$ adsorption/desorption reactions were introduced into the denitration reaction model and the $\mathrm{NH}_{3}$ surface coverage was used to characterize the number of $\mathrm{NH}_{3}$ overlying the active center of the catalyst. Meanwhile, the denitration reactions such as the standard SCR reaction, the fast SCR reaction, the slow SCR reaction, and the oxidation reaction of the $\mathrm{NH}_{3}$ were all carried out based on the adsorbed $\mathrm{NH}_{3}$ rather than the gas phase $\mathrm{NH}_{3}$ - so the reaction pathway can be simplified to a 6-step surface reaction [26,27], as shown in Table 4.

Table 4. SCR reaction pathway and reaction rate.

\begin{tabular}{cccc}
\hline NO. & Reaction Formula & Pre-Exponential Factor & $\begin{array}{c}\text { Activation Energy Ea } \\
(\mathbf{J} / \mathbf{k m o l})\end{array}$ \\
\hline $\mathrm{R} 1$ & $\mathrm{NH}_{3}(\mathrm{~g})+\mathrm{V}(\mathrm{s}) \rightarrow \mathrm{NH}_{3} \cdot \mathrm{V}(\mathrm{g})$ & $6.7 \times 10^{8}$ & 0 \\
$\mathrm{R} 2$ & $\mathrm{NH}_{3} \cdot \mathrm{V}(\mathrm{s}) \rightarrow \mathrm{NH}_{3}(\mathrm{~g})+\mathrm{V}(\mathrm{s})$ & $1.0 \times 10^{13}$ & $8.4 \times 10^{4}$ \\
$\mathrm{R} 3$ & $4 \mathrm{NH}_{3} \cdot \mathrm{V}(\mathrm{s})+4 \mathrm{NO}(\mathrm{g})+\mathrm{O}_{2}(\mathrm{~g}) \rightarrow 4 \mathrm{~N}_{2}+6 \mathrm{H}_{2} \mathrm{O}+4 \mathrm{~V}(\mathrm{~s})$ & $5.0 \times 10^{12}$ & $7.5 \times 10^{4}$ \\
$\mathrm{R} 4$ & $4 \mathrm{NH}_{3} \cdot \mathrm{V}(\mathrm{s})+2 \mathrm{NO}(\mathrm{g})+2 \mathrm{NO}_{2}(\mathrm{~g}) \rightarrow 4 \mathrm{~N}_{2}(\mathrm{~g})+6 \mathrm{H}_{2} \mathrm{O}(\mathrm{g})+4 \mathrm{~V}(\mathrm{~s})$ & $8.0 \times 10^{3}$ & $6.5 \times 10^{4}$ \\
$\mathrm{R} 5$ & $8 \mathrm{NH}_{3} \cdot \mathrm{V}(\mathrm{s})+6 \mathrm{NO}_{2}(\mathrm{~g}) \rightarrow 7 \mathrm{~N}_{2}(\mathrm{~g})+12 \mathrm{H}_{2} \mathrm{O}(\mathrm{g})+8 \mathrm{~V}(\mathrm{~s})$ & $3.0 \times 10^{3}$ & $7.1 \times 10^{4}$ \\
$\mathrm{R} 6$ & $4 \mathrm{NH}_{3} \cdot \mathrm{V}(\mathrm{s})+3 \mathrm{O}_{2}(\mathrm{~g}) \rightarrow 2 \mathrm{~N}_{2}(\mathrm{~g})+6 \mathrm{H}_{2} \mathrm{O}(\mathrm{g})+4 \mathrm{~V}(\mathrm{~s})$ & $1.7 \times 10^{13}$ & $2.0 \times 10^{5}$ \\
\hline
\end{tabular}

\subsection{Nitrate Passivation Reaction Model}

Considering the SCR reaction occurs primarily between $\mathrm{NH}_{3}$ and $\mathrm{NOx}$ and that the diesel exhaust contains a large amount of moisture, the formation of deposits such as ammonium nitrate is one of the unavoidable side reactions. Deposits such as nitrate block the surface or the pores of the catalyst, preventing the adsorption of the gas phase ammonia. Therefore, the nitrate passivation reaction is assumed to occur between the gas phase $\mathrm{NO}_{2}$ and the adsorbed $\mathrm{NH}_{3}$ to form the surface phase (solid) nitrate. Taking into consideration that the decomposition products of nitrate at high temperature are $\mathrm{HNO}_{3}$ and $\mathrm{N}_{2} \mathrm{O}$, the nitrate passivation reaction pathway can be simplified into four surface reactions [19-22], as presented in Table 5.

Table 5. Nitrate passivation reaction pathway.

\begin{tabular}{cccc}
\hline No. & Reaction Formula & Pre-Exponential Factor & $\begin{array}{c}\text { Activation Energy Ea } \\
\text { (J/kmol) }\end{array}$ \\
\hline $\mathrm{R} 1$ & $2 \mathrm{NH}_{3} \cdot \mathrm{V}(\mathrm{s})+2 \mathrm{NO}_{2}(\mathrm{~g}) \rightarrow \mathrm{N}_{2}(\mathrm{~g})+\mathrm{NH}_{4} \mathrm{NO}_{3} \cdot \mathrm{V}(\mathrm{s})+\mathrm{H}_{2} \mathrm{O}+\mathrm{V}(\mathrm{s})$ & $3.4 \times 10^{-2}$ & 0.0 \\
$\mathrm{R} 2$ & $\mathrm{NH}_{4} \mathrm{NO}_{3} \cdot \mathrm{V}(\mathrm{s}) \rightarrow \mathrm{NH}_{3}(\mathrm{~g})+\mathrm{HNO}_{3}(\mathrm{~g})+\mathrm{V}(\mathrm{s})$ & 10.0 & 26.0 \\
$\mathrm{R} 3$ & $\mathrm{NH}_{3} \cdot \mathrm{V}(\mathrm{s})+\mathrm{HNO}_{3}(\mathrm{~g}) \rightarrow \mathrm{NH}_{4} \mathrm{NO}_{3} \cdot \mathrm{V}(\mathrm{s})$ & $1.1 \times 10^{-6}$ & 0.0 \\
$\mathrm{R} 4$ & $\mathrm{NH}_{4} \mathrm{NO}_{3} \cdot \mathrm{V}(\mathrm{s}) \rightarrow \mathrm{N}_{2} \mathrm{O}(\mathrm{g})+2 \mathrm{H}_{2} \mathrm{O}(\mathrm{g})+\mathrm{V}(\mathrm{s})$ & $7.5 \times 10^{9}$ & $1.1 \times 10^{3}$ \\
\hline
\end{tabular}




\subsection{Sulfate Passivation Reaction Model}

In this paper, it was assumed that $\mathrm{SO}_{2}$ reacts directly with metal ions on the active center, causing it to lose activity. In addition, ammonium sulfate is formed by the reaction of $\mathrm{SO}_{3}$ with ammonia gas and decomposed to form ammonium bisulfate, etc.- - finally it is decomposed into $\mathrm{SO}_{2}$ and ammonia. Both reaction processes consume the active site of the catalyst, in turn reducing its activity.

Based on this, nitrate passivation reaction occurs between the gas phase $\mathrm{SO}_{3}$ and the adsorbed $\mathrm{NH}_{3}$ to form a surface phase (solid) sulfate, which is a reversible reaction. Simultaneously, the poisoning reaction of sulfate is assumed to occur between the gas phase $\mathrm{SO}_{2}$ and the active material, which is an irreversible reaction. Thus, nitrate passivation reaction can be simplified to a 6-step chemical reaction [12-18], as shown in Table 6.

Table 6. Sulfate passivation reaction pathway.

\begin{tabular}{cccc}
\hline No. & Reaction Formula & Pre-Exponential Factor & $\begin{array}{c}\text { Activation Energy Ea } \\
\text { (J/kmol) }\end{array}$ \\
\hline $\mathrm{R} 1$ & $\mathrm{~V}(\mathrm{~s})+\mathrm{SO}_{2}(\mathrm{~g}) \rightarrow \mathrm{SO}_{2} \cdot \mathrm{V}(\mathrm{s})$ & $1.3 \times 10^{-4}$ & 0.0 \\
$\mathrm{R} 2$ & $\mathrm{SO}_{2}(\mathrm{~g})+0.5 \mathrm{O}_{2}(\mathrm{~g}) \rightarrow \mathrm{SO}_{3}(\mathrm{~g})$ & 1.2 & 40.0 \\
$\mathrm{R} 3$ & $\mathrm{SO}_{3}(\mathrm{~g})+\mathrm{H}_{2} \mathrm{O}(\mathrm{g})+2 \mathrm{NH}_{3} \cdot \mathrm{V}(\mathrm{s}) \rightarrow\left(\mathrm{NH}_{4}\right)_{2} \mathrm{SO}_{4} \cdot \mathrm{V}(\mathrm{s})+\mathrm{V}(\mathrm{s})$ & 0.5 & 0.0 \\
$\mathrm{R} 4$ & $\left(\mathrm{NH}_{4}\right)_{2} \mathrm{SO}_{4} \cdot \mathrm{V}(\mathrm{s}) \rightarrow \mathrm{NH}_{4} \mathrm{HSO}_{4} \cdot \mathrm{V}(\mathrm{s})+\mathrm{NH}_{3}(\mathrm{~g})$ & $2.3 \times 10^{10}$ & $1.1 \times 10^{2}$ \\
$\mathrm{R} 5$ & $2 \mathrm{NH}_{4} \mathrm{HSO}_{4} \cdot \mathrm{V}(\mathrm{s}) \rightarrow\left(\mathrm{NH}_{4}\right)_{2} \mathrm{~S}_{2} \mathrm{O}_{7} \cdot \mathrm{V}(\mathrm{s})+\mathrm{H}_{2} \mathrm{O}(\mathrm{g})+\mathrm{V}(\mathrm{s})$ & $7.9 \times 10^{9}$ & $1.3 \times 10^{2}$ \\
$\mathrm{R} 6$ & $3\left(\mathrm{NH}_{4}\right)_{2} \mathrm{~S}_{2} \mathrm{O}_{7} \cdot \mathrm{V}(\mathrm{s}) \rightarrow 2 \mathrm{NH}_{3}(\mathrm{~g})+2 \mathrm{~N}_{2}(\mathrm{~g})+6 \mathrm{SO}_{2}(\mathrm{~g})+9 \mathrm{H}_{2} \mathrm{O}(\mathrm{g})+3 \mathrm{~V}(\mathrm{~s})$ & $7.2 \times 10^{12}$ & $1.6 \times 10^{2}$ \\
\hline
\end{tabular}

\section{Simulation Model Verification}

The SCR reaction model constructed in this paper consists of the $\mathrm{NH}_{3}$ adsorption/desorption reaction, the SCR denitrification reaction, the nitrate formation/decomposition reaction, and the sulfate formation/decomposition reaction. In order to verify the accuracy of the construction model, the four reaction processes were simulated separately and were compared with the relevant experimental data.

\subsection{Confirmation of the Adsorption/Desorption Reaction Pathway}

Referring to the adsorption/desorption reaction of vanadium-based catalysts by Luca Lietti et al. [28,29], this section carried out the simulation verification of the $\mathrm{NH}_{3}$ adsorption/desorption reaction process. Amongst them, the test time was set at $3000 \mathrm{~s}$ and the inlet $\mathrm{NH}_{3}$ concentration was $700 \mathrm{ppm}$. In addition, $\mathrm{N}_{2}$ was the equilibrium gas and the initial exhaust gas temperature was $220^{\circ} \mathrm{C}$. After $t=750 \mathrm{~s}$ the supply of $\mathrm{NH}_{3}$ was stopped and after $t=1500 \mathrm{~s}$ the temperature raised to $595^{\circ} \mathrm{C}$ at $0.25^{\circ} \mathrm{C} / \mathrm{s}$. Test and simulation results are shown in Figure 18.

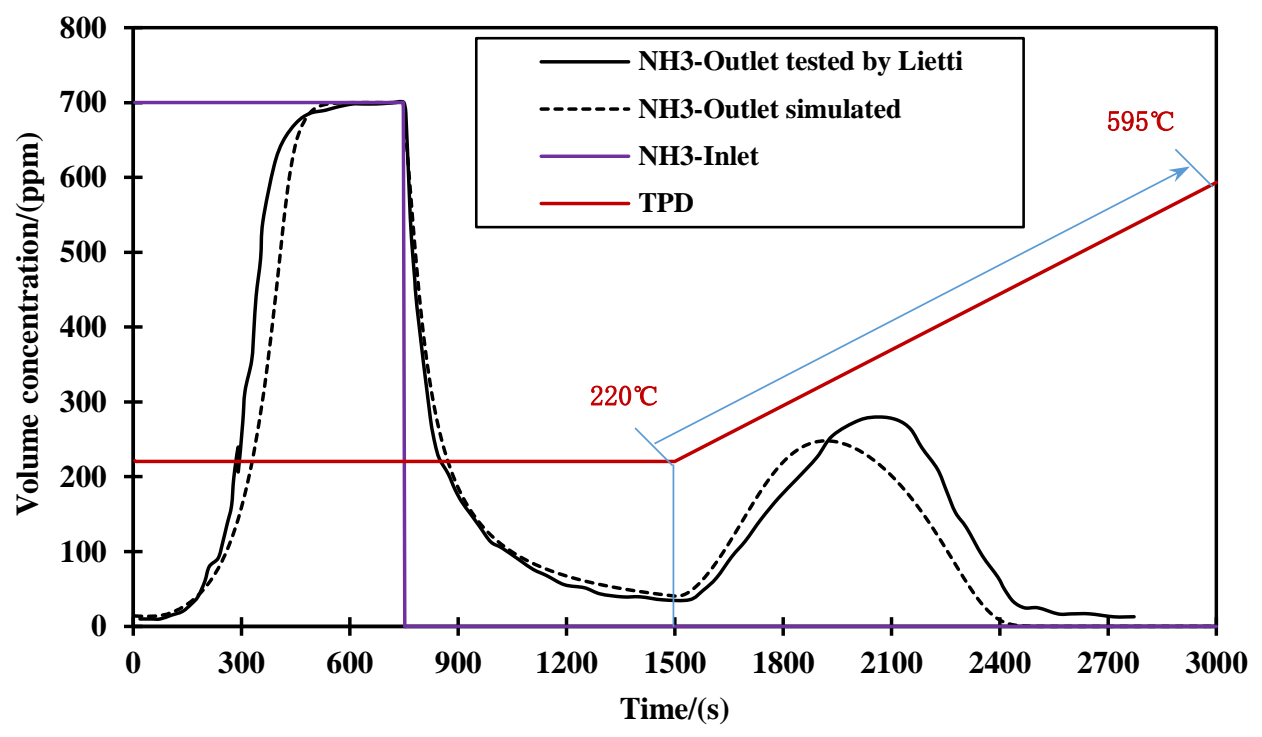

Figure 18. Simulation verification of the $\mathrm{NH}_{3}$ adsorption and desorption reaction. 
As shown in Figure 18, the simulation and experimental values for the $\mathrm{NH}_{3}$ adsorption/ desorption reaction are basically the same. In addition, the $\mathrm{NH}_{3}$ adsorption process occurs during the period from $t=0-500 \mathrm{~s}$ while the temperature-programmed desorption process during the period from $t=150-2500 \mathrm{~s}$, respectively. The $\mathrm{NH}_{3}$ adsorption/desorption reaction is mainly affected by factors such as the reaction temperature, the surface property of the catalyst, and the internal surface area of the catalyst. Therefore, the physical property of the catalyst surface is defined as the same in the simulation model, which means that the effect of surface property (internal and external diffusion characteristics) on the adsorption/desorption process is ignored. Hence, the simulated values of the $\mathrm{NH}_{3}$ adsorption rate and desorption rate are faster than the experimental values during the $\mathrm{NH}_{3}$ adsorption phase and the temperature-programmed desorption phase. Moreover, the actual peak maximum error is within $10 \%$.

\subsection{SCR Denitration Reaction Pathway Validation}

This section explores the simulation verification of the SCR denitration reaction process, which was carried out by taking into consideration the denitration reaction test of the vanadium-based catalysts by Luca Lietti et al. [28,29]. Among them, the test time was set at $3000 \mathrm{~s}$ and the $\mathrm{NH}_{3}$ concentration was $1000 \mathrm{ppm}$ at the reactor inlet. In addition, $\mathrm{NO}$ and $\mathrm{O}_{2}$ concentration were $700 \mathrm{ppm}$ and $1 \%$, respectively. Moreover, Helium $(\mathrm{He})$ was the equilibrium gas, the initial exhaust gas temperature was $220^{\circ} \mathrm{C}$, and the supply of $\mathrm{NH}_{3}$ was stopped after $t=1000 \mathrm{~s}$. The test and the simulation results are shown in Figure 19.

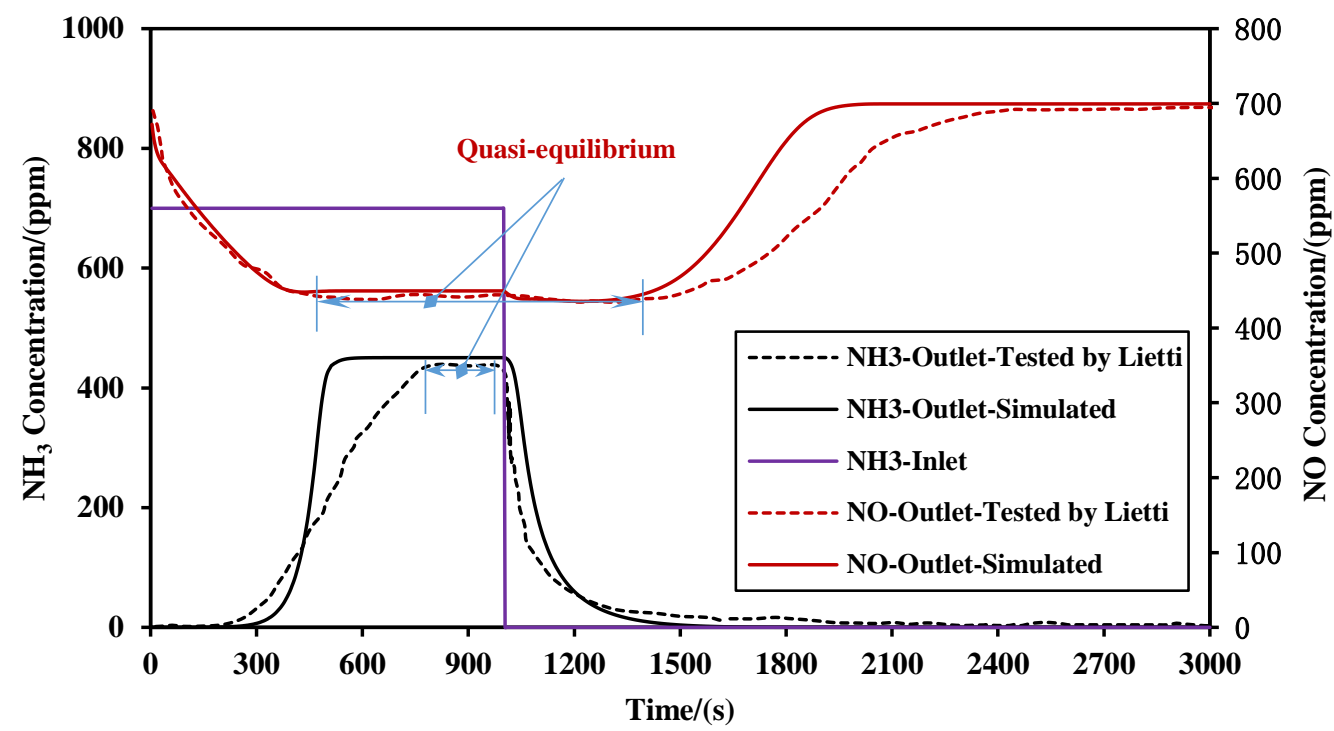

Figure 19. Simulation verification of the SCR denitration reaction process.

As shown in Figure 19, the simulation values of $\mathrm{NH}_{3}$ and $\mathrm{NO}$ outlet concentration are consistent with the variation trend of their test values and both values are in good agreement after the reaction is stabilized. However, there is a certain error when the reaction is not stable (from 300 to $800 \mathrm{~s}$ and from 1400 to $2400 \mathrm{~s}$ ). Since the $\mathrm{NH}_{3}$ adsorption/desorption reaction and the denitration reaction occur simultaneously during the SCR reaction process, the $\mathrm{NH}_{3}$ adsorption reaction tends to be stable (from 300 to $800 \mathrm{~s}$ ) after the SCR denitration reaction reaches quasi-equilibrium. In addition, during the period from 1400 until $2400 \mathrm{~s}$ the $\mathrm{NH}_{3}$ desorption reaction tends to be stable before the SCR denitration reaction reaches quasi-equilibrium. Because the simulation model ignored the effect of the catalyst's surface physical properties (internal and external diffusion characteristics) on the adsorption/desorption process, the influence of the $\mathrm{NH}_{3}$ adsorption rate and the desorption rate of the simulation values were faster than the test values. Moreover, the simulation values of $\mathrm{NH}_{3}$ outlet concentration were higher than the experimental values during the period from 300 until $800 \mathrm{~s}$. 
Furthermore, the NO outlet concentration simulation values were higher than the experimental values during the period from 1400 until $2400 \mathrm{~s}$. However, the simulation values agreed well with the test values after the two reactions reached quasi-equilibrium.

\subsection{Verification of the Passivation Reaction Pathway of Ammonium Nitrate}

Based on the denitration reaction of the vanadium-based catalysts and the reaction of ammonium nitrate formation by Cristian Ciardelli et al. [22], the simulation verification of the ammonium nitrate formation/decomposition reaction process was carried out in this section. The test time was $6000 \mathrm{~s}$ and the reaction temperature was $175^{\circ} \mathrm{C}$. In addition, the equilibrium gas was $\mathrm{N}_{2}$ and the concentrations of $\mathrm{NH}_{3}, \mathrm{NO}, \mathrm{NO}_{2}, \mathrm{O}_{2}$, and $\mathrm{H}_{2} \mathrm{O}$ were $1000 \mathrm{ppm}, 750 \mathrm{ppm}, 250 \mathrm{ppm}, 2 \%$, and 1\%, respectively. Moreover, $\mathrm{NH}_{3}$ was introduced into the exhaust gas in the beginning and stopped at $t=6500 \mathrm{~s}$ while NOx was introduced at $t=3000 \mathrm{~s}$. The test and simulation results are shown in Figure 20.

As shown in Figure 20, the simulated values for the outlet concentrations of $\mathrm{NH}_{3}, \mathrm{NO}_{2}$ and $\mathrm{N}_{2} \mathrm{O}$ are consistent with the experimental values during the SCR denitration reaction process. Since the simulation model ignored the effect of the catalyst surface physical property (internal and external diffusion characteristics) on the adsorption/desorption process, the simulation values of $\mathrm{NH}_{3}$ 's adsorption and desorption rates were faster than the experimental values, leading to higher simulation values for the outlet concentrations of $\mathrm{NO}_{2}$ and $\mathrm{N}_{2} \mathrm{O}$ before and after the reaction stability. However, the simulated values agreed well with the experimental values after the reaction reached quasi-equilibrium.

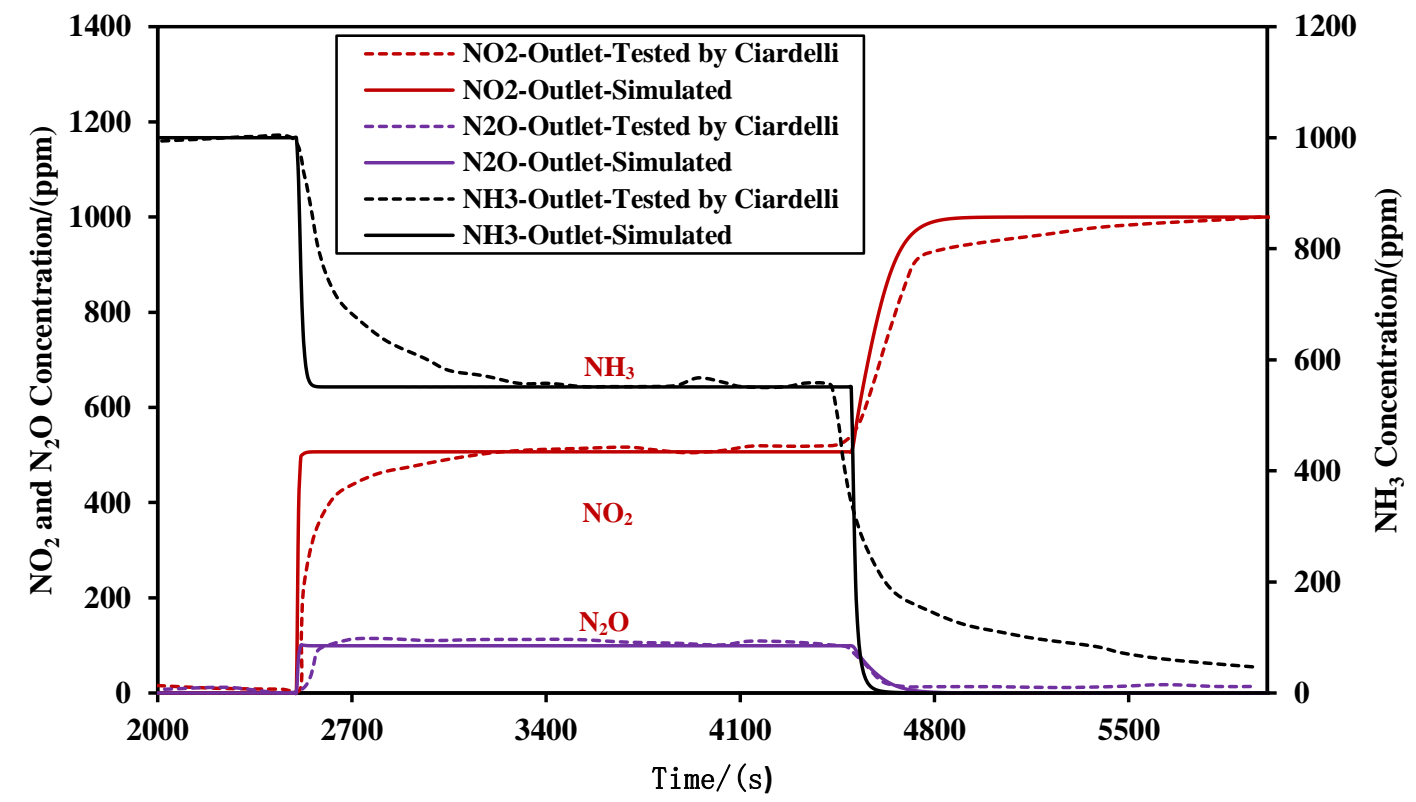

Figure 20. The change of outlet concentration of each component in the SCR system over time.

\subsection{Verification of Sulfate Passivation Reaction Pathway}

In this section, the simulation verification of the sulfate formation/decomposition reaction process was carried out depending on the $\mathrm{SO}_{2}$ oxidation reaction test and the sulfur poisoning test of Tengfei $\mathrm{Xu}$ et al. [18]. During the $\mathrm{SO}_{2}$ oxidation reaction test, the space velocity was $120,000 \mathrm{~h}^{-1}$ and the equilibrium gas was Nitrogen $\left(\mathrm{N}_{2}\right)$. In addition, the concentration of $\mathrm{SO}_{2}$ and $\mathrm{O}_{2}$ were 1000 ppm and $5 \%$, respectively. The test and simulation results of the $\mathrm{SO}_{2}$ conversion efficiency at different temperatures are shown in Figure 21. 


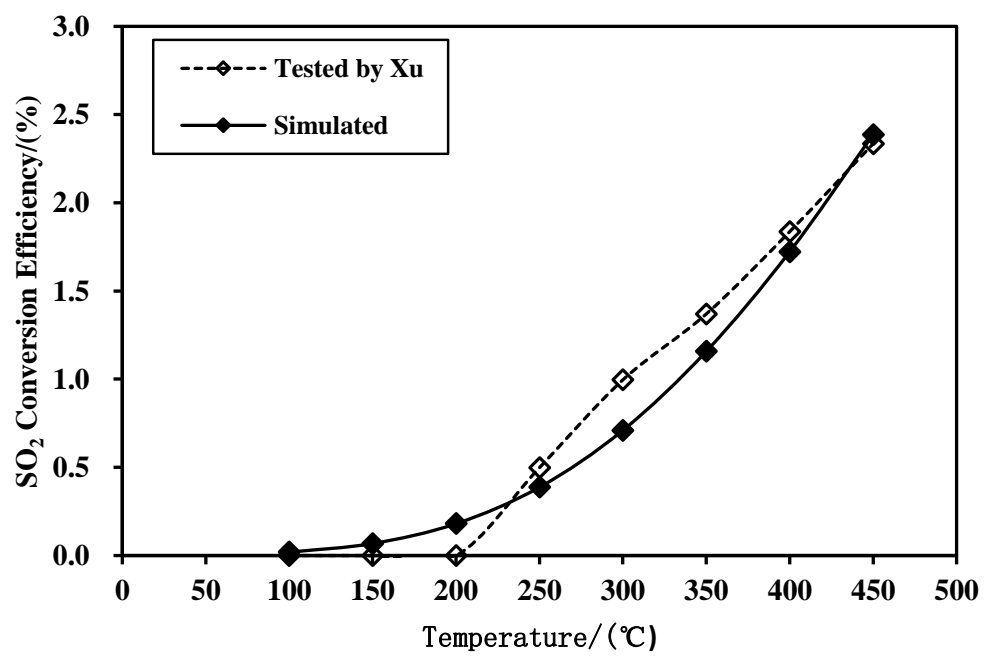

Figure 21. Experimental and simulation results of $\mathrm{SO}_{2}$ conversion efficiency at different temperatures.

As shown in Figure 21, the experimental values of $\mathrm{SO}_{2}$ conversion efficiency at different temperatures are consistent and agree well with the trend of the simulated values. When the temperature is between 250 and $450{ }^{\circ} \mathrm{C}$, the experimental value of $\mathrm{SO}_{2}$ conversion efficiency is slightly larger than the simulated value because during the experiment, a small amount of adsorbed $\mathrm{SO}_{2}$ reacts with $\mathrm{O}_{2}$ gas molecules.

The speed velocity was $5000 \mathrm{~h}^{-1}$ and the equilibrium gas was $\mathrm{N}_{2}$ during the test of anti-sulfur poisoning. Furthermore, the concentrations of $\mathrm{NH}_{3}, \mathrm{NO}, \mathrm{SO}_{2}, \mathrm{O}_{2}$, and $\mathrm{H}_{2} \mathrm{O}$ were 1000 ppm, 1000 ppm, $1000 \mathrm{ppm}, 5 \%$, and $10 \%$, respectively. The experimental values of denitration efficiency at different temperatures are consistent with the simulation values and the data is in good agreement as shown in Figure 22.

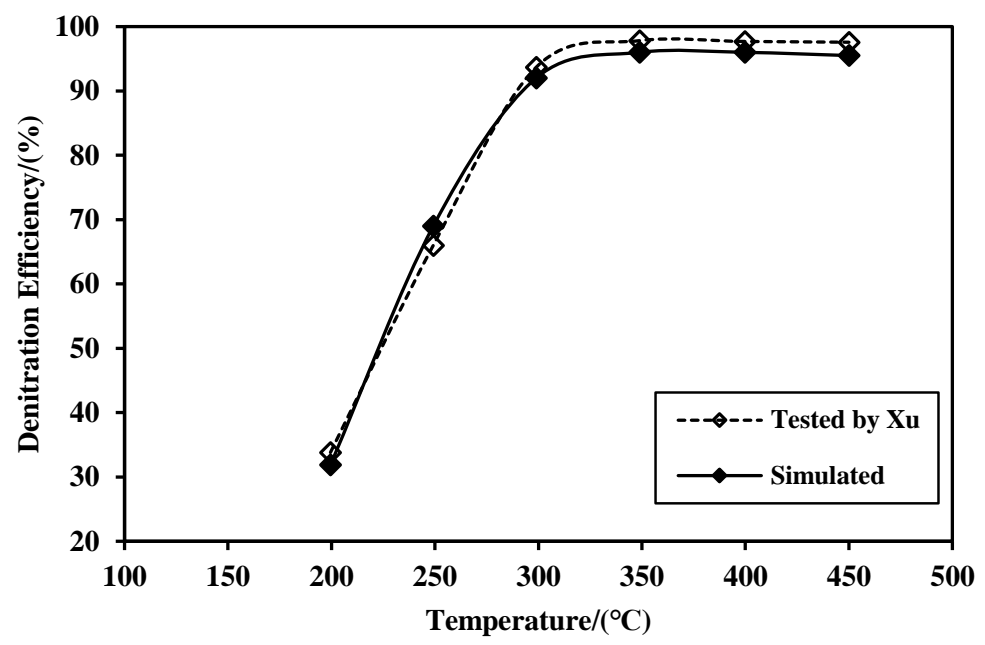

Figure 22. Experimental and simulation results of denitration efficiency at different temperatures.

\section{Conclusions}

(1) Using the one-dimensional simulation software, the ammonium salt passivation reaction model was embedded in the surface denitration reaction model and the SCR system simulation model was constructed. The nitrate passivation reaction process, the sulfate passivation reaction process and their influencing factors were simulated, respectively. The model accuracy of the adsorption/desorption reaction, the denitrification reaction, the nitrate passivation reaction, and the sulfate passivation reaction were correspondingly verified. 
(2) Based on the SCR system simulation model, the catalytic temperature and the requirements of the vanadium-based catalysts were analyzed. In addition, the nitrate passivation reaction process and its influencing factors were studied. Moreover, the $\mathrm{NO}_{2} / \mathrm{NO}_{\mathrm{x}}$ ratio and the exhaust gas temperature range formed by the ammonium nitrate were determined, and the ammonium nitrate passivation reaction characteristics were obtained. Furthermore, the study found that $\mathrm{NO}_{2}$ was the main reactant of the $\mathrm{NH}_{4} \mathrm{NO}_{3}$ formation reaction. The $\mathrm{SCR}$ denitration efficiency and $\mathrm{NH}_{4} \mathrm{NO}_{3}$ production increased with the increase of the $\mathrm{NO}_{2} / \mathrm{NO}_{x}$ ratio from 0 to 0.25 in a temperatures range of 175 to $250{ }^{\circ} \mathrm{C}$-with the $\mathrm{NO}_{2} / \mathrm{NO}_{\mathrm{x}}$ ratio having a major influence on the denitration efficiency. But the $\mathrm{NH}_{4} \mathrm{NO}_{3}$ generated can also decompose into a small amount of $\mathrm{N}_{2} \mathrm{O}$ at the same time. Therefore, within a certain range, the increased of the $\mathrm{NO}_{2} / \mathrm{NO}_{\mathrm{x}}$ ratio was beneficial to the rapid SCR reaction and the $\mathrm{NH}_{4} \mathrm{NO}_{3}$ formation reaction, while the increased of the exhaust gas temperature was beneficial to the rapid SCR reaction and the $\mathrm{NH}_{4} \mathrm{NO}_{3}$ decomposition reaction, respectively.

(3) Based on the SCR system simulation model, the sulfate passivation process and its influencing factors were studied. In addition, the composition concentration of the ammonium sulfate and the temperature range of the exhaust gas were determined and the passivation reaction characteristics of ammonium sulfate were obtained. It was found that the influence of the $\mathrm{SO}_{2}$ concentration on the denitration efficiency decreased with the increased exhaust gas temperature because of the increasing of SCR reaction rate and the reversibility of ammonia sulfate formation. Moreover, at $325^{\circ} \mathrm{C}$, the denitration efficiency was only $6 \%$ under the condition of $100 \mathrm{ppm}$ and $1000-\mathrm{ppm} \mathrm{SO}_{2}$ concentration. Moreover, $\mathrm{SO}_{3}$ was an important reactant for the formation of sulfate, but the rate of sulfate decomposition increased with the increased reaction temperature. However, when the exhaust gas temperature was lower than $300^{\circ} \mathrm{C}$, the SCR denitration efficiency decreased with time under high sulfur conditions, and almost had no change when the exhaust gas temperature was higher than $350^{\circ} \mathrm{C}$. Thus, ammonia bisulfate had almost no impact on the catalyst activity.

Author Contributions: Conceptualization, Y.Z., S.Z. and Y.F.; Funding acquisition, Y.Z.; Project administration, Y.Z.; Software, L.Y. and C.X.; Writing—original draft, Y.Z. and Q.H.; Writing—review \& editing, Y.Z. and M.S.

Funding: We gratefully acknowledge the financial support of the National Key Research and Development Program of China (No. 2016YFC0205400), and the Provincial Funding for National Projects of Heilongjiang Province in China (No. GX17A020).

Conflicts of Interest: The authors declare no conflict of interest. And the funders had no role in the design of the study; in the collection, analyses, or interpretation of data; in the writing of the manuscript, or in the decision to publish the results

\section{References}

1. A CIMAC Working Group-Exhaust Emissions Control. Guide to Diesel Exhaust Emissions Control of NOx, SOx, Particulates, Smoke and $\mathrm{CO}_{2}$-SEAGOING Ships and Large Stationary Diesel Power Plants; The International Council on Combustion Engines: Frankfurt Germany, 2008.

2. Fung, F.; Zhu, Z.; Becque, R.; Finamore, B. Prevention and Control of Shipping and Port Air Emissions in China; Natural Resources Defense Council: New York, NY, USA, 2014.

3. MAN Energy Solutions. MAN BEW Two-Stroke Marine Engines Emission Project Guide for Marpol Annex VI Regulations, 9th ed.; MAN Energy Solutions: Augsburg, Germany, 2018.

4. Ministry of Transport of the People's Republic of China. Adjustment Plan for Marine Emission Control Areas-Draft for Soliciting Opinions; Ministry of Transport of the People's Republic of China: Beijing, China, 2018.

5. International Maritime Organization (IMO). Final Report of the Correspondence Group on Assessment of Technological Developments to Implement the Tier III NOx Emission Standards under MARPOL Annex VI; MEPC 65/4/7; International Maritime Organization: London, UK, 2013.

6. Zhu, Y.; Zhou, S.; Feng, Y.; Wang, Z. Influence of $\mathrm{NH}_{4} \mathrm{NO}_{3}$ formation on the NOx reduction pathways over vanadium-based catalyst under diesel exhaust conditions. Russ. J. Phys. Chem. A 2018, 92, 1473-1480.

7. Zhu, Y.; Zhang, R.; Zhou, S.; Huang, C.; Feng, Y.; Shreka, M.; Zhang, C. Performance Optimization of High-pressure SCR System in a Marine Diesel. Part II: Catalytic Reduction and Process. Top. Catal. 2018. [CrossRef] 
8. Bendrich, M.; Scheuer, A.; Hayes, R.E.; Votsmeier, M. Unified mechanistic model for Standard SCR, Fast SCR, and $\mathrm{NO}_{2}$ SCR over a copper chabazite catalyst. Appl. Catal. B Environ. 2018, 222, 76-87. [CrossRef]

9. Magnussona, M.; Fridell, E.; Ingelstenc, H.H. The influence of sulfur dioxide and water on the performance of a marine SCR catalyst. Appl. Catal. B Environ. 2012, 111-112, 20-26. [CrossRef]

10. Han, B.; Shen, Y.; Zhu, S.; Liu, Y.; Shen, S. Promotional effect of phosphorylation on CeSn0.8W0.6Ox/TiAl0.2Si0.1Oy for $\mathrm{NH}_{3}$-SCR of NO from marine diesel exhaust. J. Rare Earths 2016, 34, 1010-1016. [CrossRef]

11. Cimino, S.; Lisi, L.; Tortorelli, M. Low temperature SCR on supported MnOx catalysts for marine exhaust gas cleaning: Effect of $\mathrm{KCl}$ poisoning. Chem. Eng. J. 2016, 283, 223-230. [CrossRef]

12. Wang, Y.; Ge, D.; Che, M.; Gao, S.; Wu, Z. A dual-functional way for regenerating $\mathrm{NH}_{3}-\mathrm{SCR}$ catalysts while enhancing their poisoning resistance. Catal. Commun. 2018, 117, 69-73. [CrossRef]

13. Li, X.; Liu, C.; Li, X.; Peng, Y.; Li, J. A neutral and coordination regeneration method of Ca-poisoned $\mathrm{V}_{2} \mathrm{O}_{5}-\mathrm{WO}_{3} / \mathrm{TiO}_{2} \mathrm{SCR}$ catalyst. Catal. Commun. 2017, 100, 112-116. [CrossRef]

14. Li, X.; Li, X.; Yang, R.T.; Mo, J.; Li, J.; Hao, J. The poisoning effects of calcium on $\mathrm{V}_{2} \mathrm{O}_{5}-\mathrm{WO}_{3} / \mathrm{TiO}_{2}$ catalyst for the SCR reaction: Comparison of different forms of calcium. Mol. Catal. 2017, 434, 16-24. [CrossRef]

15. Thogersen, J.R.; Slabiak, T.; White, N. Ammonium Bisulphate Inhibition of SCR Catalysts; Haldor Topsoe Inc.: Frederikssund, Denmark, 2010.

16. Ma, S.; Jin, X.; Sun, Y.; Cui, J. The formation mechanism of ammonium bisulfate in SCR Flue gas denitrification process and control. Therm. Power Gener. 2010, 39, 12-17.

17. Chen, C.; Cao, Y.; Liu, S.; Chen, J.; Jia, W. Review on the latest developments in modified vanadium-titanium-based SCR catalysts. Chin. J. Catal. 2018, 39, 1347-1365. [CrossRef]

18. Xu, T.; Wu, X.; Gao, Y.; Lin, Q.; Hu, J.; Weng, D. Comparative study on sulfur poisoning of $\mathrm{V}_{2} \mathrm{O}_{5}-\mathrm{Sb}_{2} \mathrm{O}_{3} / \mathrm{TiO}_{2}$ and $\mathrm{V}_{2} \mathrm{O}_{5}-\mathrm{WO}_{3} / \mathrm{TiO}_{2}$ monolithic catalysts for low-temperature $\mathrm{NH}_{3}$-SCR. Catal. Commun. 2017, 93, $33-36$. [CrossRef]

19. Nova, I.; Ciardelli, C.; Tronconi, E.; Chatterjee, D.; Bandl-Konrad, B. $\mathrm{NH}_{3}-\mathrm{NO} / \mathrm{NO}_{2}$ chemistry over V-based catalysts and its role in the mechanism of the Fast SCR reaction. Catal. Today 2006, 114, 3-12. [CrossRef]

20. Ciardelli, C.; Nova, I.; Tronconi, E.; Chatterjee, D.; Burkhardt, T.; Weibel, M. $\mathrm{NH}_{3} \mathrm{SCR}$ of NOx for diesel exhausts aftertreatment: Role of $\mathrm{NO}_{2}$ in catalytic mechanism, unsteady kinetics and monolith converter modelling. Chem. Eng. Sci. 2007, 62, 5001-5006. [CrossRef]

21. Nova, I.; Ciardelli, C.; Tronconi, E.; Chatterjee, D.; Weibel, M. $\mathrm{NH}_{3}-\mathrm{NO} / \mathrm{NO}_{2} \mathrm{SCR}$ for diesel exhausts after treatment: Mechanism and modelling of a catalytic converter. Top. Catal. 2007, 42, 43-46. [CrossRef]

22. Ciardelli, C.; Nova, I.; Tronconi, E.; Chatterjee, D.; Bandl-Konrad, B.; Weibel, M.; Krutzsch, B. Reactivity of $\mathrm{NO} / \mathrm{NO}_{2}-\mathrm{NH}_{3} \mathrm{SCR}$ system for diesel exhaust aftertreatment: Identification of the reaction network as a function of temperature and $\mathrm{NO}_{2}$ feed content. Appl. Catal. B Environ. 2007, 70, 80-90. [CrossRef]

23. Ertl, G.; Knözinger, H.; Weitkamp, J. (Eds.) Handbook of Heterogeneous Catalysis; Wiley-VCH Verlag GmbH \& Co.: Weinheim, Germany, 2008.

24. GT-SUITE. Exhaust Aftertreatment-Application Manual, Ver. 7.5; Gamma Technology: Pune, India, 2016.

25. Ebrahimian, V.; Nicolle, A.; Habchi, C. Detailed modeling of the evaporation and thermal decomposition of urea-water solution in SCR systems. AIChE J. 2012, 58, 1998-2009. [CrossRef]

26. Topsoe, N.Y.; Topsoe, H.; Dumesic, J.A. Vanadia/Titania catalysts for selective catalytic reduction (SCR) of nitric oxide by ammonia: I. Combined temperature programmed in situ FTIR and on-line mass spectroscopy studies. J. Catal. 1995, 151, 226-240. [CrossRef]

27. Topsoe, N.Y.; Dumesic, J.A.; Topsoe, H. Vanadia/Titania catalysts for selective catalytic reduction (SCR) of nitric oxide by ammonia: II. Studies of active sites and formulation of catalytic cycle. J. Catal. 1998, 151, 241-252. [CrossRef]

28. Lietti, L.; Nova, I.; Camurri, S.; Tronconi, E.; Forzatti, P. Dynamics of the SCR-DeNOx reaction by the transient-response method. AIChE J. 1997, 43, 2559-2570. [CrossRef]

29. Lietti, L.; Nova, I.; Tronconi, E.; Forzatti, P. Transient kinetic study of the SCR-DeNOx reaction. Catal. Today 1998, 45, 85-92. [CrossRef]

(C) 2018 by the authors. Licensee MDPI, Basel, Switzerland. This article is an open access article distributed under the terms and conditions of the Creative Commons Attribution (CC BY) license (http://creativecommons.org/licenses/by/4.0/). 